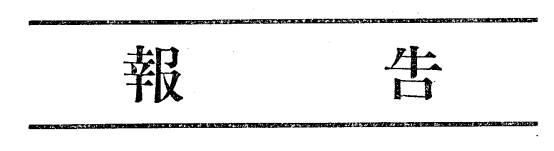

\title{
學校照明現狀調查報告
}

昭和 12 年 10 月 1 日

學校照明推獎照度調查委員會

委員長松 田長三郎

㕵團法人 照 明 學 會

照明智識普及委員會關西委員會

\section{委員長鳥養利三郎 殿}

手啓谷々御隆昌奉賀候 陳者去る昭和11年 4 月學校照明推獎照度調查方御委囑相受候に付同 年 5 月 8 日第 1 回委員會開催以來推獎照度決定に必要なる資料索得る䉆先づ

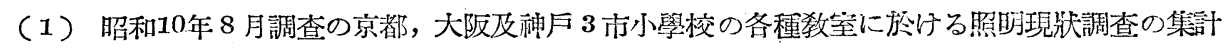

（2）小學校兒童及中等學校生徒の快適照度の調查

(3) 我國に於沙る從來の學校照明推獎照度調查

(4) 外國に於汀る學校照明推獎照度調查

(5) 其 他

を行ふととと致し目下之れが調枯研究續行中に有之候處今回第 1 項「學校照明現狀調查.の集計」 を完了致候條兹に御報告申上候 敬具

本調香委員會委員つ氏名は次の如し

\begin{tabular}{|c|c|c|}
\hline 委員長 & 松 田 長 三 & 郎（京都帝國大學） \\
\hline 委 員 & 上 光 & 雄（大阪市電氣局） \\
\hline 同 & 得 & 義（神戸市電氣局） \\
\hline 同 & 侁 伯 光 太 & 郎（京都電燈株式會社） \\
\hline 同 & 石 英 & 男 (東京電氣株式會社) \\
\hline 同 & 故森 脇 武 次 & 郎（京都市電氣局） \\
\hline
\end{tabular}

1. 緒

$\overline{\overline{\bar{n}}}$

學童の視力を護るてとは刻下の急務である。ての爲に敎室の照明を檢討し，之が向上を計る 必要のあるてとは云ふまでるない。ての點に鑑みて照明智識普及委員會關西委員會に於て, 昭 和10年 8 月京阪神三市小學校に就きその照明の現狀を調查し, 虽媝員會に於てその結果老集計 して茲に報告する次第である。

\section{2. 調 查學 校}

京阪神 3 都市の小學校に就き調查したもので，各市とも調查校數は學校總數の約 1 割とし， 


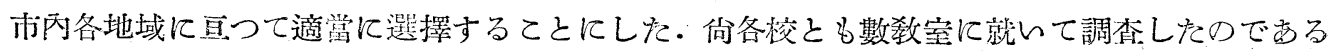

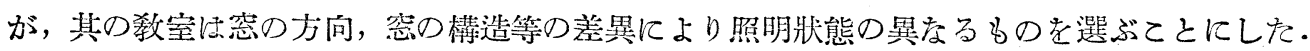
その結果調查せる學校及敎室壮次の通りである。

\begin{tabular}{|c|c|c|c|c|c|c|c|c|c|}
\hline \multirow{2}{*}{ 都 } & \multirow{2}{*}{ 市 } & \multirow{2}{*}{ 名 } & \multicolumn{2}{|l|}{ 學 } & 校 & c & \multicolumn{2}{|l|}{ 敨 } & \multirow{2}{*}{$\begin{array}{l}\text { 數 } \\
\text { 詮十 }\end{array}$} \\
\hline & & & 住宅地域 & 瀜籍地域 & 工栄地域 & 計 & 勗通敎空 & 特別呚室 & \\
\hline 索 & 都 & 市 & 9 & 6 & 4 & 19 & 117 & 47 & 164 \\
\hline 大 & 阪 & 市 & 8 & 11 & 6 & 25 & 156 & 21 & 177 \\
\hline \multirow[t]{2}{*}{ 神 } & F & 市 & 4 & 6 & 5 & 15 & 48 & 26 & 74 \\
\hline & 郭 & & 21 & 23 & 15 & 59 & 321 & 94 & 415 \\
\hline
\end{tabular}

他に讙堂 20 , 集會場 1 , 雨天體操場 1 .

\section{3. 調 查 期 間}

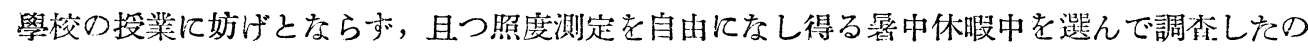
であつて，各都市に於ける調查期間は次の通りである。

\begin{tabular}{lll|lll}
\hline 京 & 都 & 市 & 昭和 10 年 & 自 8 月 5 日 & 至 8 月 30 日 \\
大 & 阪 & 市 & $\prime$ & 自 8 月 19 日 & 至 8 月 29 日 \\
神 & F & 市 & $y$ & 自 8 月 6 日 & 至 8 月 23 日 \\
\hline
\end{tabular}

\section{4. 調 沓方 法}

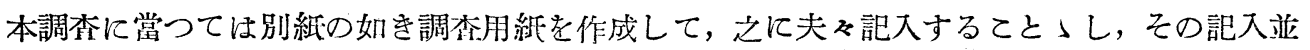
に測定方法の概要を, 該用紌の下部に記載して, 調查の統一を計つだ. 調查け學校所在地の各 電氣供給事業者に，調查用紙を邆附して依賴した。

\section{5. 集計に就て}

(1) 調榃せる學校及敉室の地域及建學構造別數

第 1 表の 1 の通りである. 表中特别教室とあるは理科, 地歴, 手工等の敎室であつて, その 內譯は第 1 表の 2 の通りである。

但特別敎公の中には集會場, 雨天體操場各 1 室を含んでるる. 又表中夜間测定數は畫間测定 せるものの中，電燈設備のある棎に就き調查せる室數である。

（2）天井及壁の色合別敉空數.

第 2 表の通りである。表中明，中，喑々記載せるほ天井，壁の反射狀態を示したるのである が，其の範圍は測定橥の感じによつて決定せるを以て，多少不正確をる點するる巳むを得ない 次第である。

\section{（3）密掛の有螌及色合別㕁室數}

第 3 表の通りである。

(4) 學年別机の高さ

第 4 表の通りである。本表は普通㸚室の机の高さを，學年別に集計したるので，學校により 
机の高さは非常に相違せるも, その平均の高さは大體學級に應じて漸次高くなつてみる。 神戶市の調査では學年の明訅がないから省略した。

(5) 前列の机より黑板の後の壁迄の距離別敉室數

第 5 表の通りである. 前列の机より，黑权を取付けをる壁までの距離が，餘り小なる時は， 黑板面の前列座席より遠き側が，角度の關係上非常に見難くなるを以つて，この見地より本調 查を行つたのである。本表中には講堂其他黑板の哭き敎室は含まれてるない。

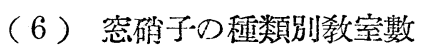

第 6 表の通りである．表中第 3 段に「其の他」とある恃金網入透明硝子,金網入卅透明确子， 金網入鄷消㗂子，金網入波模樣㗂子等を示す。

（ 7 ） 悹の高さ别敎室數

第 7 表の通りである。

(8) 天井から悹までの距離別教室數

第8表の通りである。

(9) 畫間照明の現状調查表.

第 9 表の 1 の通りである. 本表に注講堂, 集會室, 雨天體操場を含めてない. 合本表各闌に 就て說明を加ふれ汸次の通りである。

（イ）本表は空側の數, 床面積に對する悹面䆅の割合, 照度, 黑板の光澤つ有無, 黑板面の

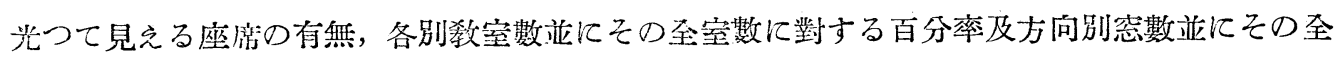
空數澲する百分率を示しなるのである。

（口）本表中「悹側の數」闌の上段 1，2，3，の數は一室の悹側の數を示し，下段にその室

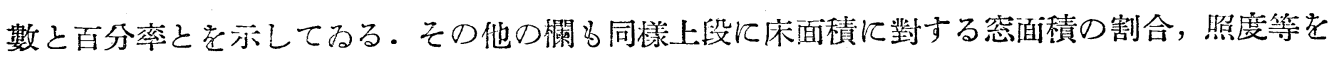
示し下段に室數と百分率とを揭げてある. 何黑板の照度, 呚卓中央の照度, 黑板の光澤, 黑板 の光つて見える座席の各闌中の空數つ合計が調查室數と合致せざるものあるる，之は特別敎室

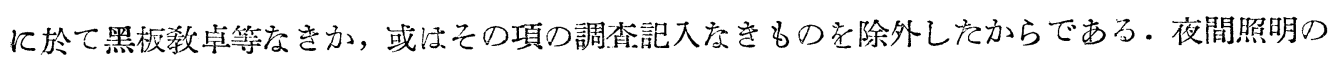
現狀調查表に於ても同㴝である。

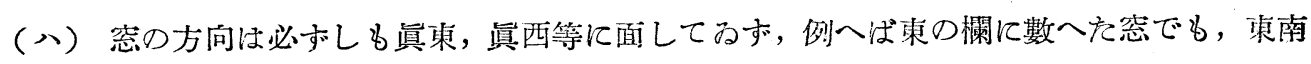
或は束北に面したものがあるが，多少をりとる東に近いるのは全部東とし，南或は北に近いる のは南或は北々しをのである。

（二）照度心，普通の光電池照度計を使用して测定してのであるから，5ルクス以下 5,000

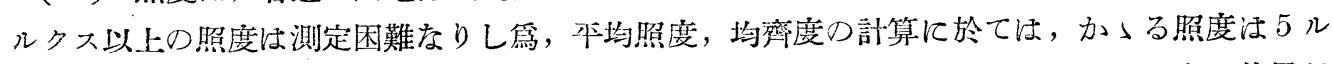
クス或は 5,000ルクスとして取扱つをのである. 佮照度は天候, 時間等によつて非常に差異が あるが屋外の照度を测定してるないから, 之学或る禋準の狀態の照度に換算することは不可能 である、從つて测定時つ照度考其の㦎探用するてとにしたのである。

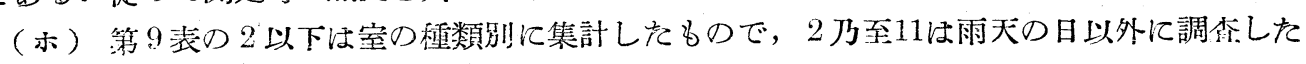

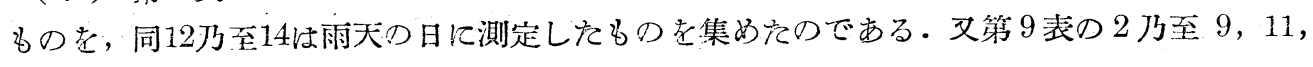


12，14は第 9 表の 1 之同樣の方法で集計したが，10及13は 1 室又は 2 室しか調尛されてねない ものだけを集め竞るので，從つて室數並にその百分率は，各欄に示してなん。

（へ）本調杳に於ては調查校圭，商業地域，工業地域，任宅地域に區分したのであるが，實 際には其の地域が確然と區分されないるの当すり, 又其の地域の差異が照明に餘り影響がない と認めたので, ての地域別には何等考慮してない。

（ト）空の方向と照度とは，相當關係があると思はれるが，之は時間的に大きな影響があり， その關係を本調查の結果から求めることは出來なかつた。

（チ）空面樍と床佰積の比と照度との關係, 天井及壁の色合と照度との關係等は, 照度を測 定しを時の天候，時閏等が同一條件になつてるないから承的てない。

（リ）悹硝子の種類及悹つ高さと均齊度の關係は，他の條件が相當影響して複雜になるから

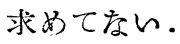

（10）夜間照明の現狀調查表

第10表の 1 の通りである・晌本表各闌に就いで說明を加ふれば次の通りである。

（イ）本表は燈數别, 總ワット數, 床面積, 1 平方米當りワット數, 照度, 電暜, 電燈器具, 笠の 型, 笠の材質, 電球の種類, 黑板の光つて見える座席の有無の各別室數, 並にその企室數に對 する百分率を示しえるのである。笠の型及材質，並に電球の種類欄の百分率㳊省略した。

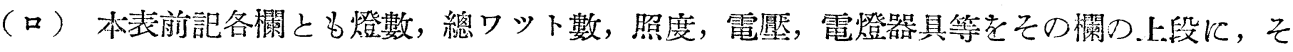
の室數と百分率を下段に示してある. 何電燈器具, 笠の型及材質, 電球の種類各欄の室數合計 が調查室數より大忩るものあるる，之は混用せる室を重複記入したからである。

（ハ）本表の照度は，测定時に於ける照度をその㦎集計したものである。第10表の11は1室 しふ調高されてるないるのだけを，室の種類別に集めたるので,從つて室數亚にその百分率は， 各闌に示してない。

刃邦文タイプライター敨室は，夜間照明のみ調查され党ものである。

(11) ワット別電燈數

第11表の通りである。

(12) 机上面からの電燈の高ざ

第12表の通りである。

\section{6. 結言}

本調查は京，阪，神 3 市の全小學校に就て行つたものではをいが，3市の各地域に亘り，木 造, 鐵筋コンクリート透の各校舍を選んで調枯し, 普通敉室の如きは, その數 320 稌の多きに 澾してなるから，之を以つて 3 市小學校の照明の現狀を，十分窺ふてとが出來ると思ふ。以下 本調查の結果から見た照明の現狀に就ての所見を述べて，調查報告を結ぶてとにする。

（1）天井，壁及カーテンの色合等に就て

天井，壁の色合は，中程度のものが大多數を占めてるる。壁の下部は中程度の色合でも良い 
が，天井は出來得る限り明るい色合が望ましい，天井，壁の色合の隌いてとは，敉意內の照度

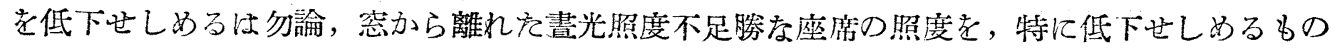
であつて，畫光照明の均齊度を良好ならしめろ上からも考慮す心゙きである。天゙半，壁の色合の 中程度以下に腤きものは, 多くはその污損によるものであつて, 天井, 壁等活 3 年に 1 度位明 るい色に塗替へられるてとを望む为のである。

カーテンの色合も, 中程度以下に暗いものが多いが，暗室とする篇に便用するカーテン以外 は，天井，壁と同樣明るん方が良い。

( 2 ） 前列の机より黑板迄つ距離に就て

限られをる呚室に，多數の學童を收容しなければならない關係もあつて，前列の机と黑板と

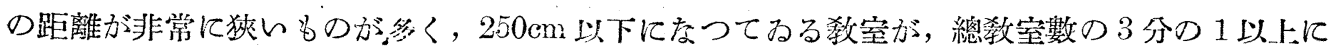
達してみる狀態で西る。普通呚室に於て, 長さ $4 \mathrm{~m}$ の黑板が使用されてみるものとすれば， その黑板の端から，中心の方一約 $50 \mathrm{~cm}$ 寄りてる位置に書かれを，黑板上の文字等を見る場合，

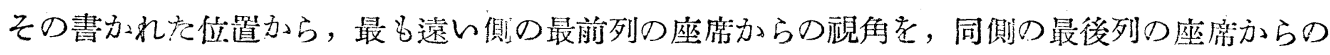
視角之同一又はそれ以上に保つ爲には，最前列の机を，黑板面から $250 \mathrm{~cm}$ 以上離さなければ ならない。ての點から前列の秃より黑板の後の壁までの距離を，250 cm 以下に縮めることはよ くないと思ふのである。

\section{(3) 㝕の高さに就て}

壳側が室の一側にだけである場合に於て, 空から遠い座席の机上の書光照度をも, 相當良好

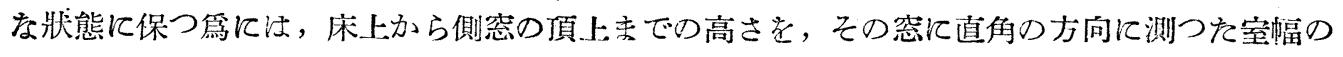
2 分の 1 以上にする必要があると云忱てるる。調稝した教室の中には，2方或は 3 方に空のあ

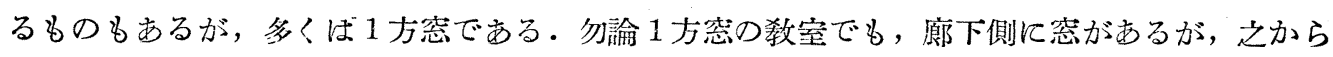
受ける書光は微々たるものである，從つて之等つ敎公つ側悹つ頂上までの高さは，之の側空が

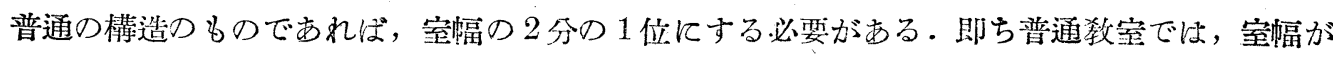

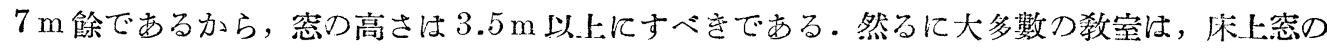
高さが 3 m以下である。

空の高さは，天井の高さに關係し，建築費の制限を受けて止む得ない場合もあると思ふが， 第 8 表主是ると，天井から空の、部までの距離が $50 \mathrm{~cm}$ 以上もある敉室が，約 3 分の 1 を占め てるる状態ですつて，之等つ多くは，天゙井の高さ者變へずに，空を高くする狳地があると思ふ のである・

\section{（4）畫光照度に就て}

書光による本均照度を見れば，机上に於て 200 ルクス上つ室が奎調查室の $85 \%$ 以上，黑 板上に於て 100 ルクス以上を有するものが $73 \%$ 以上洼してるるから大體良好であるとも云 へるが，その最低照度を見る時，机上照度が僅か60ルクス未淽しかない机のある室が，全數 の約 $40 \%$ ，黑板面上に 60 ルクス未滿の照度の處がある室が，約 $30 \%$ と友んでるる狀態であ 
る. 然も之等の照度は，1年中で最も明るい筈つ季節に調查された結果であるてとを思人代， 一䚄寒心に堪へないのである。

晌机上の最高照度と最低照度との比が，20 以上に及んでるる敎室が約牛數に達してるる. 之を見ても，密側の座席が非常に明るい場合にも，空から遠い座塺の暲いものが多いてとが制 るのである．即ち現在の如き㮖造の側空が，敎室の 1 側つみに設けられた場合は，空と反對側 の机上の畫光照度が, 晴天の日にる不足するてとが多いのである. 女季節, 時間, 天候等によ つて，書光照度の不足することは屡々起る筈であるから，か〉る場合には，その照度の不足す る場所は, 電燈によつて補强する必要がある。

(5) 電燈照明汒就て

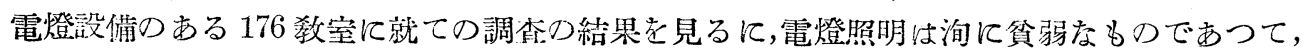
優良な照明学施せる呚室は，殆んざ皆舆の狀態である，今其の要點を列記すれば次の通りであ る。

（イ）燈數 1 敎室 5 燈乃至 6 燈つもの $65 \%$ 以上音占め，燈數の點のみより考へる時は 可良なるのが多い。

（口）照度 机上及黑板共その平均照度は低く，50ルクス末滿つもの $90 \%$ 以上に及び $10 ル$ クス未滿のものさへ多少する. 又机上照度が，10ルクスに足らない座磨のある敎室が，約 40 \%に達してるる狀態で, 今更ながら餘りにも照度の不足せるを痛感する次第でする。

又机の配置內に於ける最高照度と最低照度との差異の莧だしいるのが多いが, 之は電燈の 高さに就て，考慮を要すべき點が多いてとを示してるるつである。

（ハ）電燈器具 電燈器具としては,グローブを使用せるものより笠を使用せのものが多 く，然もその笠は，殆んぞ全部扁平をるの（P1）である．斯くては多少照度が高くても，照 明狀態は不良にしで暗輝を生じる茼れが多い筈である。

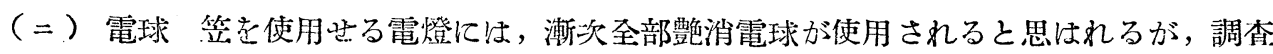
虽時には, 份透明電球を使用してわるものを認めた。

(6) 黑板照明に就て

光澤のある黑板は漸次使用されなくなつて來をが，佾調查全敉室の 4 分の 1 は光澤のある黑 板が使用せられてるる,又黑板の光つて見える座席を有する呚室は更に多く，畫間に於て約72\% 夜間に於て57\%に對してるる。黑板の光つて見えるやうな座席に着いた學童は, 黑板面の文字 等を見るのに非常に困難索感じるてとが多いから，何れの座勃から見ても，黑板に光つて見え る處がをいやらに照明しなけれぱなら索い。書光にょる照明では, 㝕の位置の關係で巳むを得 ない場合が多いと思ふが，カーテンとか，黑板つ電燈照明設供とかによつて，相當緩和するて とが出來る、又夜間に於ては電燈つ位置に注意すれば，容易に防止出來る筈である。

(7) 結 語

京阪神三沛小學校に於ける照明の現狀の全貌は, 本調查報告に示されを如く, 遺憾ながら畫

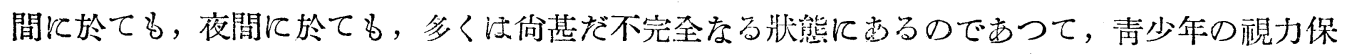
護の上に，最も重大なる閣係を有する照明狀態の改善は，刻下の急務なりと云はざるを得索い。 本調榃報告が將來一般學校に於ける照明狀態の改善に對する刺践々なり，改善促進に對する參 考資料とるなれば幸甚とする所である。 


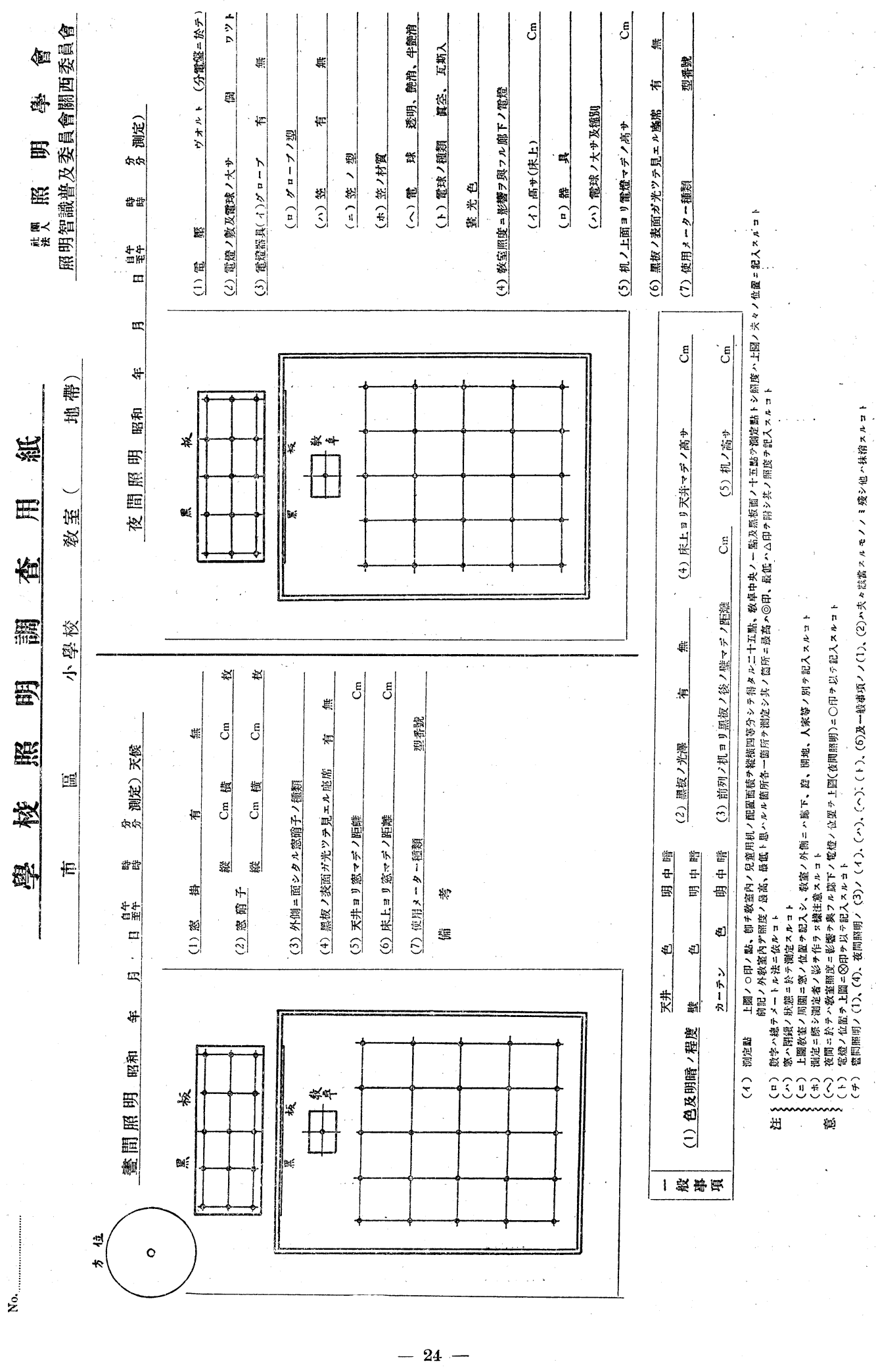


學校照明現湨調查報告

第 1 表の 1 䏱查せる學校及敉室の地域及建築構浩別數

\begin{tabular}{|c|c|c|c|c|c|c|c|c|c|c|c|c|c|}
\hline \multirow{2}{*}{ 椠造別 } & \multirow{2}{*}{ 地 域 别 } & \multirow{2}{*}{ 學松數 } & \multicolumn{4}{|c|}{ 錮:間 湘 定敎室數 } & \multicolumn{3}{|c|}{ 夜間 測定教室 數 } & \multicolumn{4}{|c|}{ 講 堂 嫩 } \\
\hline & & & $\begin{array}{ll}\text { 普 樋 } \\
\text { 肴欠 等 }\end{array}$ & $\begin{array}{l}\text { 特 } \\
\text { 教 }\end{array}$ & $\begin{array}{l}\text { 別 } \\
\text { 童 }\end{array}$ & 計 & $\begin{array}{l}\text { 普 通 } \\
\text { 致 }\end{array}$ & $\begin{array}{l}\text { 特 别 } \\
\text { 教 空 }\end{array}$ & 計 & $\begin{array}{l}\text { 贾 } \\
\text { 测 }\end{array}$ & $\begin{array}{l}\text { 間 } \\
\text { 定 }\end{array}$ & $\begin{array}{l}\text { 夜 } \\
\text { 測 }\end{array}$ & $\begin{array}{l}\text { 間 } \\
\text { 定 }\end{array}$ \\
\hline 鐵 リ & 住宅地域 & 8 & 45 & & 15 & 60 & 21 & 13 & 34 & & 2 & & 1 \\
\hline 筋, & 㫦羓地域 & 15 & 88 & & 29 & 117 & 36 & 22 & 58 & & 5 & & 4 \\
\hline$=1$ & 工業地域 & 6 & 15 & & 13 & 28 & 10 & 10 & 20 & & - & & - \\
\hline ク造 & 誴 & 29 & 148 & & 57 & 205 & 67 & 45 & 112 & & 7 & & 5 \\
\hline 木 & 住芑地域 & 13 & 82 & & 17 & 99 & 14 & 11 & 25 & & 6 & & 2 \\
\hline & 商業地域 & 8 & 31 & & 13 & 44 & 17 & 8 & 25 & & 3 & & $\mathbf{3}$ \\
\hline & 工業地域 & 9 & 60 & & 9 & 69 & 9 & 7 & 16 & & 4 & & 3 \\
\hline 造 & 計 & 30 & 173 & & 39 & 212 & 40 & 26 & 66 & & 13 & & 8 \\
\hline 總 & 計 & 59 & 321 & & 96 & 417 & 107 & 71. & 178 & & 20 & & 13 \\
\hline
\end{tabular}

第 1 表の 2 特別敎室內譯

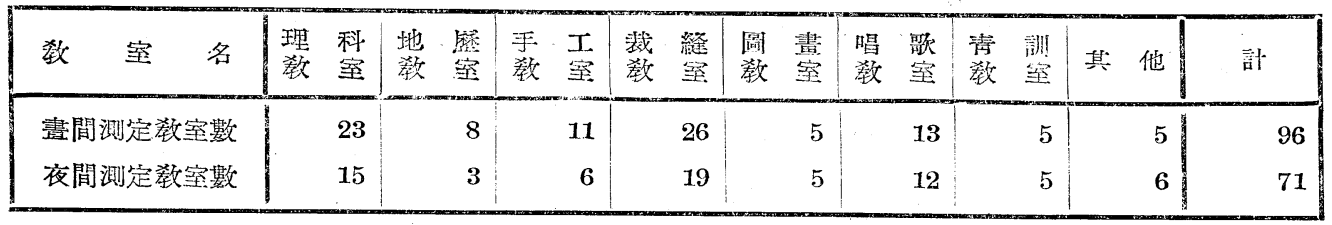

第 2 表 天井及壁の色合別敉室做

\begin{tabular}{|c|c|c|c|c|c|c|c|c|c|c|c|c|}
\hline \multirow{2}{*}{ 数 空 名 } & \multicolumn{3}{|c|}{ 天 } & \multicolumn{3}{|c|}{ 井 } & \multicolumn{6}{|c|}{ 壁 } \\
\hline & 明 & 中 & 暗 & 不 & 明 & 棓 & 明 & 中 & 暗 & 不 & 明 & 部 \\
\hline 普通敎空 & 85 & 182 & 46 & & 8 & 321 & 96 & 203 & 11) & & 12 & 321 \\
\hline 理科敦窒 & 11 & 10 & 1 & & 1 & 23 & 7 & 15 & - & & 1 & 23 \\
\hline 地感教空 & 7 & - & 1 & & - & 8 & 7 & 1. & - & & - & 8 \\
\hline 圖畫教室 & 2 & 3 & - & & -1 & 5 & 1 & 4 & - & & - & 5 \\
\hline 唱歌敎空 & 5 & 8 & - & & - & 13 & 4 & 7 & 2 & & 一 & 13 \\
\hline 裁縫敎室 & 9 & 13 & 3 & & 1 & 26 & 7 & 13 & 6 & & - & 26 \\
\hline 手工敎空 & 2 & 7 & 2 & & - & 11 & 4 & 7 & - & & - & 11 \\
\hline 㻏訓敎空 & 2 & 1. & 2 & & - & 5 & 3 & 1 & - & & 1 & 5 \\
\hline 其 他 & 1 & 4 & - & & - & 5 & 1. & 4 & - & & - & 5 \\
\hline 涻 & 124. & 228 & 55 & & 10 & 417 & 130 & 255 & 18 & & 14 & 4.17 \\
\hline 講堂 & 5 & 12 & 3 & & - & 20 & 10 & 9 & 1 & & - & 20 \\
\hline
\end{tabular}


第 3 表 悹掛の有無及色合別敎空數

\begin{tabular}{|c|c|c|c|c|c|c|c|c|c|c|c|c|c|c|}
\hline \multirow{2}{*}{ 教 室名 } & 空 & 排 & D 有 & 無 & & 密 & 掛 & の & 色 & & \multicolumn{4}{|c|}{ 密掛の明暗つ程度 } \\
\hline & 交 & 無 & 不明 & 計 & 白色 & 㫮色 & 黃色 & 其他 & 不明 & 計 & 明 & 中 & 暗 & 計 \\
\hline 㸃通敎空 & 181. & 112 & 28 & 321 & 168 & - & 10 & 1 & 2 & 181 & 67 & 90 & 24 & 181 \\
\hline 理科教室 & 17 & 3 & 3 & 23 & 3 & 11 & $\ldots$ & 3 & $-\cdot$ & 17 & 1 & 2 & 14 & 17 \\
\hline 地魏教空 & 5 & 2 & 1. & 8 & $\ldots$ & 4 & - & 1 & - & 5 & - & - & 5 & 5 \\
\hline 圖畫教空 & 3 & 1 & 1 & 5 & 2 & - & - & 1. & - & 3 & 1 & 2 & 一 & 3 \\
\hline 唱歌教空 & 11 & 2 & - & 13 & 7 & - & - & 4 & $\ldots$ & 11 & 3 & 6 & 2 & 11 \\
\hline 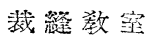 & 22 & 4 & - & 26 & 20 & - & - & 2 & - & 22 & 11 & 9 & 2 & 22 \\
\hline 手工教空 & 2 & 7 & 2 & 11 & 2 & - & -- & - & - & 2 & - & 2 & 一 & 2 \\
\hline 毒訓郄室 & 2 & 1 & 2 & 5 & 2 & - . & - & - & - & 2 & 1. & 1 & - & 2 \\
\hline 其 & 1 & 2 & 2 & 5 & 1 & - & - & - & $\ldots$ & 1 & 1. & - & - & 1 \\
\hline 計 & 244 & 134 & 39 & 417 & 205 & 15 & 10 & 12 & 2 & 244 & 85 & 112 & 47 & 244 \\
\hline 堂 & 15 & 4 & 1 & 20 & 4 & 7 & 1 & 3 & & 15 & 2 & 4 & 9 & 15 \\
\hline
\end{tabular}

空掛の色中其他の內譯

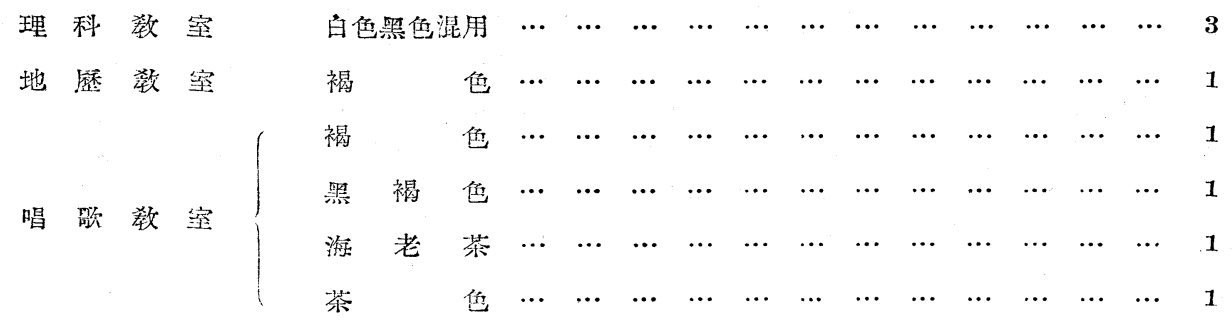

第 4 表 學年别 普通呚室の机の高さ

\begin{tabular}{|c|c|c|c|c|c|c|c|c|c|c|c|c|c|c|c|}
\hline \multirow{2}{*}{ 學 } & \multirow{2}{*}{ 年 } & \multirow{2}{*}{ 别 } & \multicolumn{3}{|c|}{ 宗 } & \multicolumn{3}{|c|}{ 都 } & \multicolumn{3}{|c|}{ 大 } & \multicolumn{2}{|r|}{ 阮 } & \multirow{2}{*}{ 平 } & \multirow{2}{*}{ 均 } \\
\hline & & & 最 & 高 & 被 & 低 & 本 & 均 & 最 & 高 & 最 & 低 & 平均 & & \\
\hline 尋 & 1 & 年 & & $53 \mathrm{~mm}$ & & $46 \curvearrowright \mathrm{m}$ & & $.9 \mathrm{~cm}$ & & $68 \mathrm{~cm}$ & & $47 \mathrm{~cm}$ & $53.1 \mathrm{~cm}$ & & $51 \mathrm{~cm}$ \\
\hline y & 2 & 年 & & 55 & & 47 & & .4 & & 68 & & 48 & 55.6 & & 53 \\
\hline "l & 3 & 年 & & 60 & & 45 & & .2 & & 58 & & 40 & 53.8 & & 54 \\
\hline y & 4 & 年 & & 60 & & 54 & & .8 & & 62 & & 54 & 57.6 & & 56.6 \\
\hline y & 5 & 年 & & 65 & & 55 & & .9 & & 60 & & 42 & 58.7 & & 59.3 \\
\hline$\nu$ & 6 & 年 & & 66 & & 56 & & .1 & & 70 & & 57 & 62.4 & & 61.7 \\
\hline 高 & 1 & 年 & & 65 & & 61.5 & & .7 & & 70 & & 55 & 64.3 & & 64 \\
\hline ly & 2 & 年 & & 69 & & 62 & & .06 & & 70 & & 64.5 & 66.2 & & 65.6 \\
\hline
\end{tabular}


第5表 前列つ机より黑板の後の壁迄の距離別敎室數

(412 新窟) 特殊教实八含マズ

\begin{tabular}{|c|c|c|c|c|c|c|c|c|}
\hline 教 空 名 & $\begin{array}{l}100 \mathrm{~cm} \\
\text { 以. T }\end{array}$ & $\begin{array}{l}100 \sim \\
200 \mathrm{~cm}\end{array}$ & $200 \sim$ & $\begin{array}{l}250 \sim \\
300 \mathrm{~cm}\end{array}$ & $\begin{array}{l}300 \sim \\
4(100 \mathrm{~cm}\end{array}$ & $\begin{array}{l}400 \mathrm{~cm} \\
\text { 以上 }\end{array}$ & 不明 & 計 \\
\hline 䇎通教空 & 2 & 15 & 86 & 165 & 46 & 4 & 3 & 321 \\
\hline 理科效空 & -- & - & 7 & 8 & 4 & 1 & 3 & 23 \\
\hline 地梧教空 & - & 4 & 1. & 3 & - & 一 & -1 & 8 \\
\hline 圖雪敎宝 & 1 & 1 & 1 & 一 & - & - & 2 & 5 \\
\hline 唱歌㫴察 & 1 & 2 & 2 & 3 & 3 & - & 2 & 13 \\
\hline 裁綡教空 & 1. & 5 & 8 & 7 & 2 & 1. & 2 & 26 \\
\hline 手工敎窒 & - & 4 & 4 & 2 & -- & - & 1 & 11 \\
\hline 青訓㻻室 & -- & 2 & 1 & 2 & - & - & - & 5 \\
\hline 郭 & 5 & 33 & 110 & 190 & 55 & 6 & 13 & 412 \\
\hline
\end{tabular}

第 6 姜 空筩子つ種類別敎室數

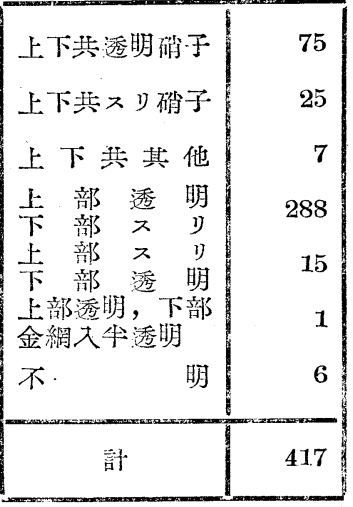

第7表悹の高さ別敎室數

\begin{tabular}{|c|c|c|c|c|c|c|c|c|}
\hline 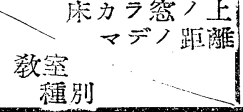 & $\begin{array}{l}200 \mathrm{~cm} \\
\text { 未 莎 }\end{array}$ & $\begin{array}{l}201 \sim \\
220 \mathrm{~cm}\end{array}$ & $221 \sim$ & $\begin{array}{l}241 \sim \\
260 \mathrm{~cm}\end{array}$ & $\begin{array}{l}261 \sim \\
280 \mathrm{~m}\end{array}$ & $\begin{array}{l}281 \sim \\
300 \mathrm{~cm}\end{array}$ & $\begin{array}{ll}3^{n} 1 \mathrm{~cm} \\
\text { 以. }\end{array}$ & 尌 \\
\hline 㿢通教空 & 6 & 3 & 20 & 30 & 85 & 103 & 74 & 321 \\
\hline 理 科 教 宝 & - & - & - & 2 & 9 & 8 & 4 & 23 \\
\hline 地 褃 教 室 & - & -- & - & 1 & 2 & 3 & 2 & 8 \\
\hline 圖 畫 敎 聜 & - & - & - & 1 & 2 & 2 & - & 5 \\
\hline 唱 歌 教 空 & - & - & - & 2 & 2 & 7 & 2 & 13 \\
\hline 裁 縺 敎 空 & 1 & - & - & 2 & 7 & 13 & 3 & 26 \\
\hline 手工㿰 空 & - & - & - & -- & 3 & 5 & 3 & 11 \\
\hline 超 訓 教 空 & - & - & - & -- & 2 & 3 & - & 5 \\
\hline 其, , 他 & - & - & - & 1 & 1 & 1 & 2 & 5 \\
\hline 計 & 7 & 3 & 20 & 39 & 113 & 145 & 90 & 417 \\
\hline 講 & - & - & 2 & - & - & $\ldots$ & 18 & 20 \\
\hline
\end{tabular}

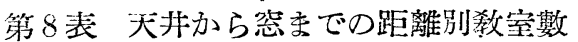

\begin{tabular}{|c|c|c|c|c|c|c|c|c|c|c|c|}
\hline 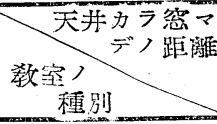 & 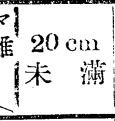 & 21 $\widetilde{30 \mathrm{~m}}$ & 31 $\widetilde{\mathrm{sm}}$ & $51 \widetilde{2 m}$ & ${ }_{60 \mathrm{~cm}}^{51}$ & 61 $\widetilde{2 m}$ & $81 \widetilde{\mathrm{cm}}$ & ${ }_{90}^{81} \widetilde{2 m}$ & 100 & $\begin{array}{l}101 \mathrm{~cm} \\
\text { 以上 }\end{array}$ & 涻 \\
\hline 嫜 涌 敨 空 & 29 & 15 & 88 & 74 & 39 & 30 & 11 & 10 & 16 & 9 & 321 \\
\hline 理 科 教 空 & 1 & - & 5 & 4 & 4 & 3 & 1. & 3 & 2 & -1 & 23 \\
\hline 地 笘 敎 窒 & 1 & - & 1 & 3 & - & 2 & 1. & - & - & - & 8 \\
\hline 圆 書 敎 室 & - & -- & 1 & 3 & - & - & - & - & 1 & -1 & 5 \\
\hline 唱 歌 敎 空 & - & 1 & 4 & 3 & 2 & - & 1 & 1 & - & 1. & 13 \\
\hline 裁 綫 教 空 & 2 & 1 & 7 & 4 & 6 & 3 & ? & 1 & - & -1 & 26 \\
\hline 手 工 教 室 & 1 & - & 3 & 2 & 2 & 2 & - & - & 1 & -1 & 11 \\
\hline 蒔 湖 教 空 & 1 & - & 2 & 2 & - & - & -- & -- & -. & -1 & 5 \\
\hline 他 & 1. & $\cdots$ & 1 & 1. & 2 & - & - & - & - & -1 & 5 \\
\hline 詁 & 36 & 17 & 112 & 96 & 55 & 40 & 16 & 15 & 20 & 10 & 417 \\
\hline 堂 & 5 & 3 & 2 & 1 & 1 & 2 & - & - & 1 & 5 & 20 \\
\hline
\end{tabular}




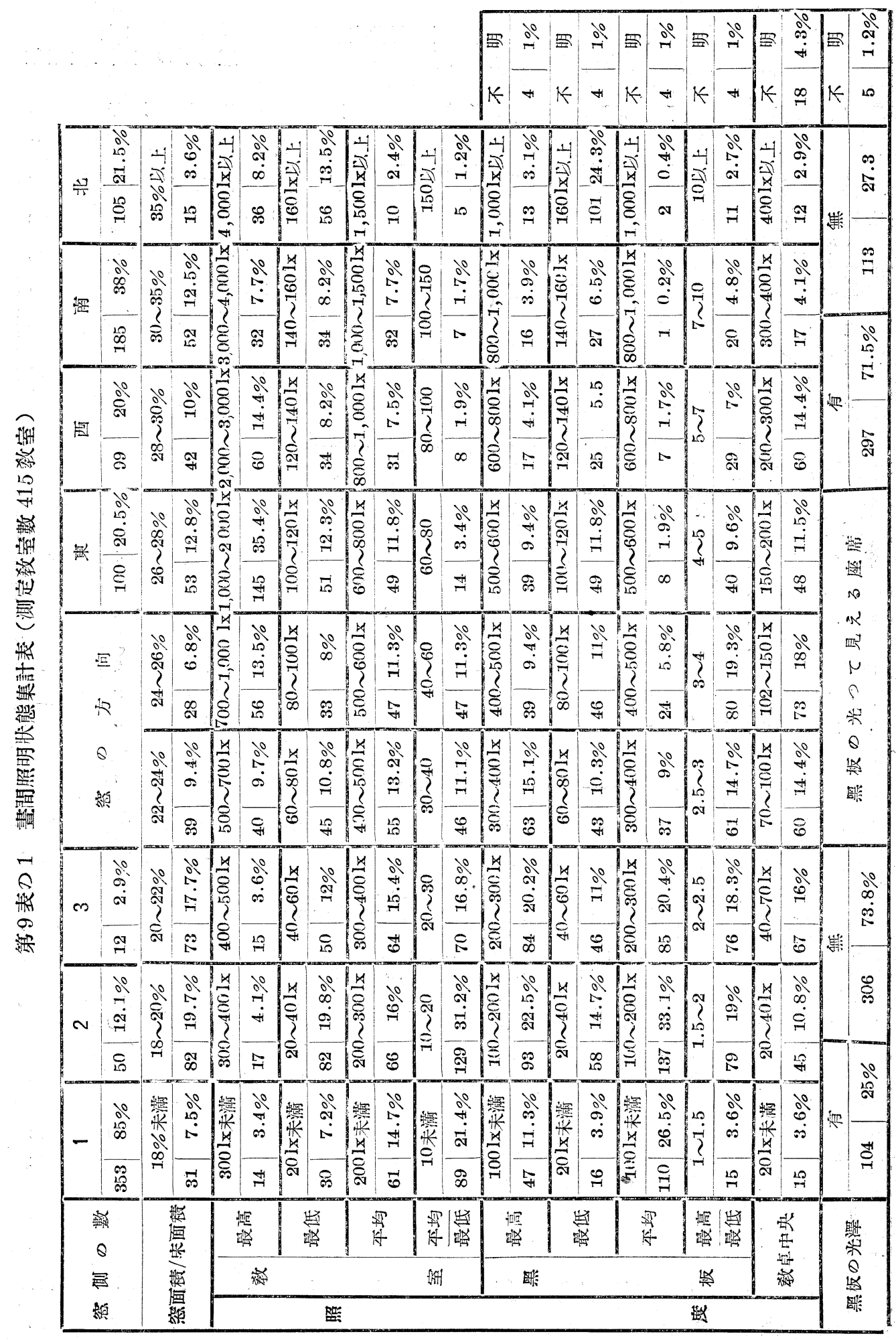




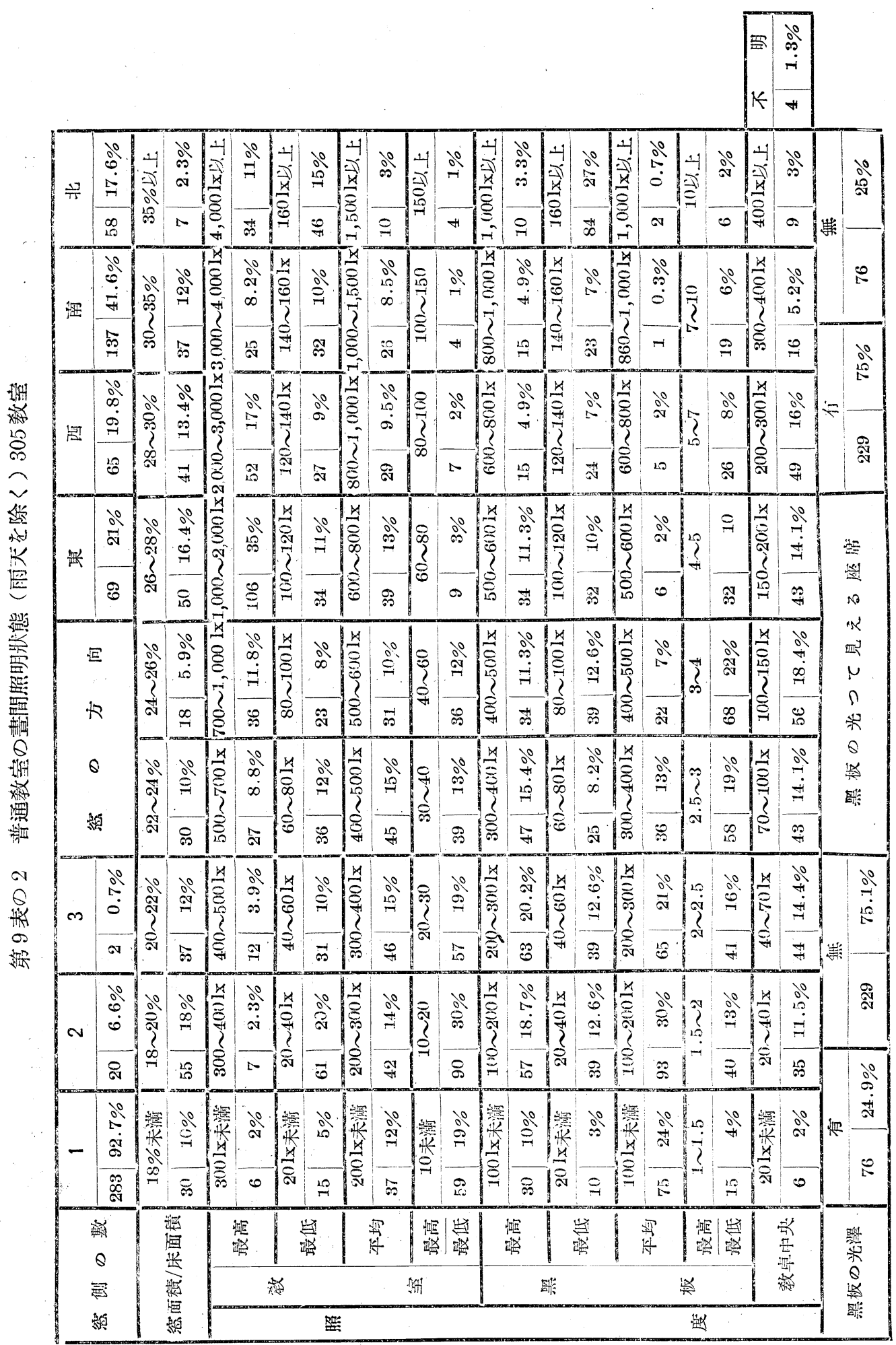




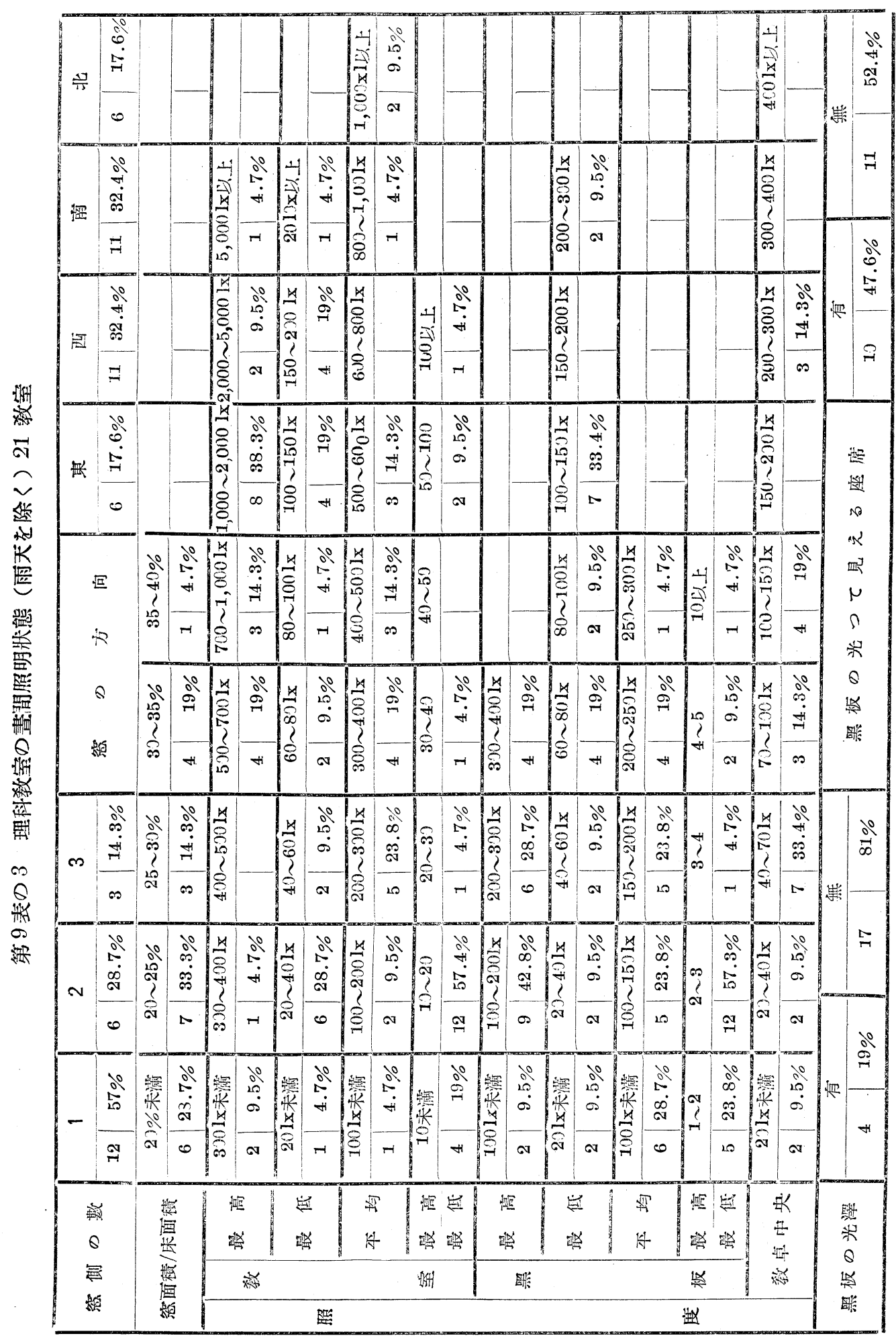




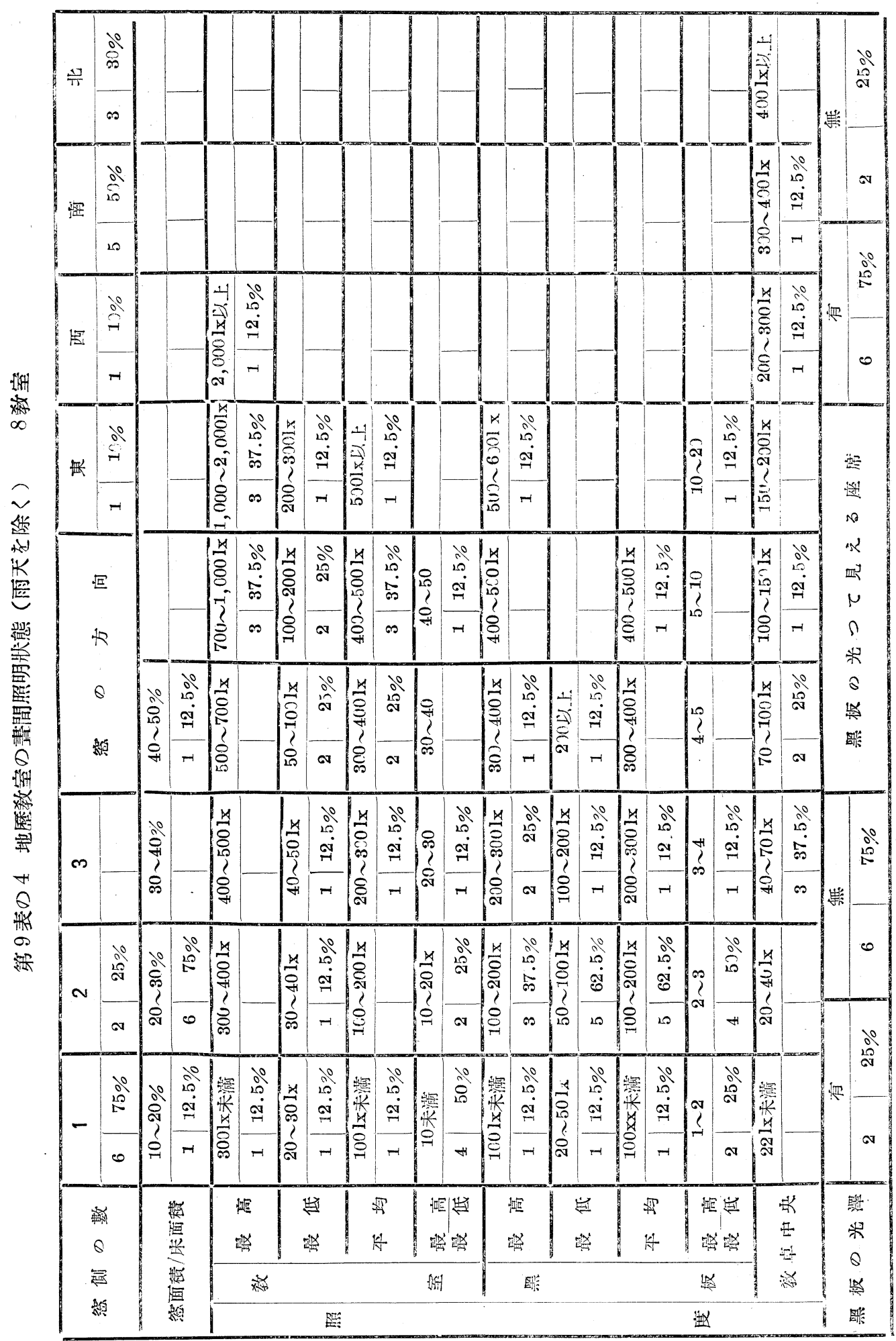




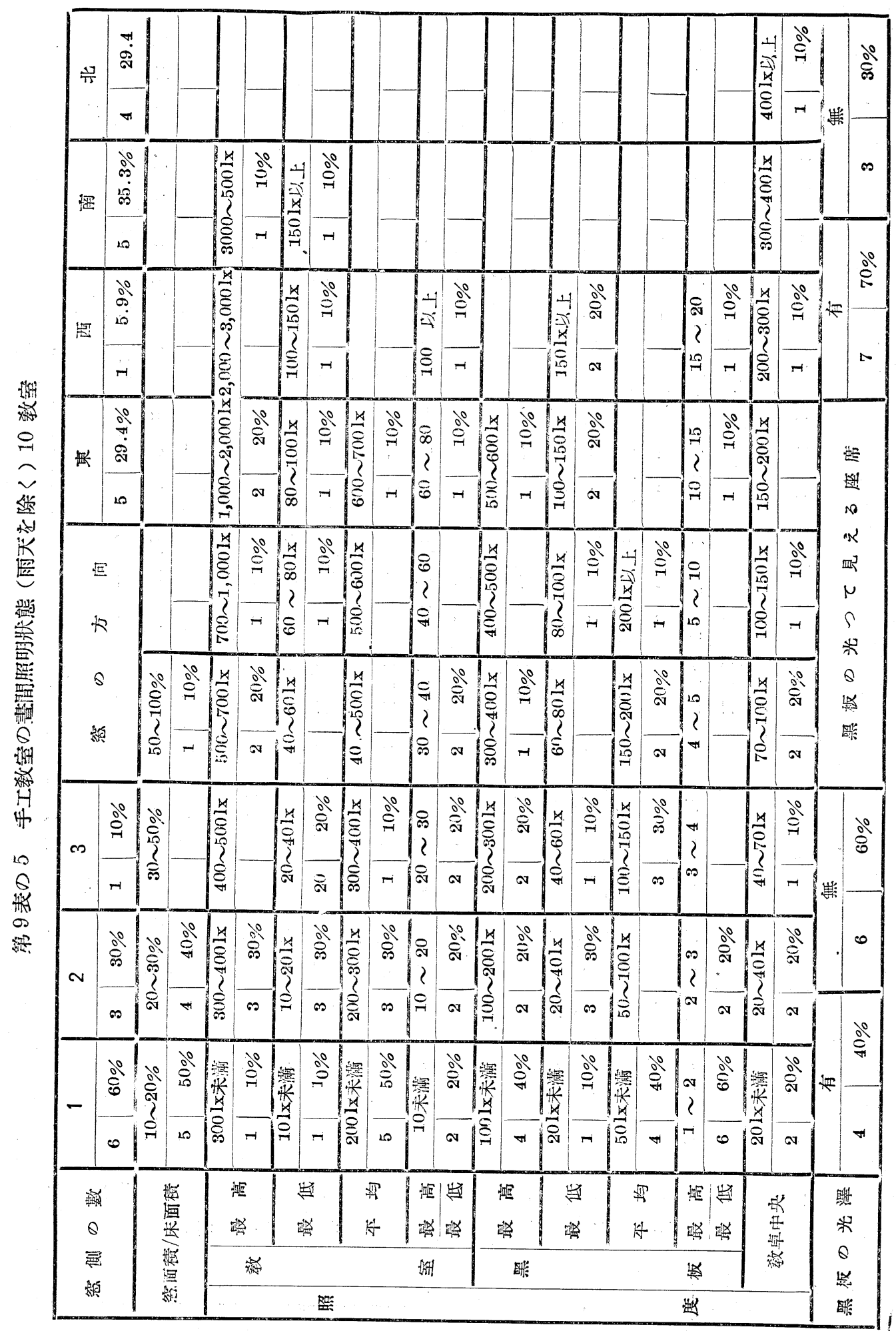




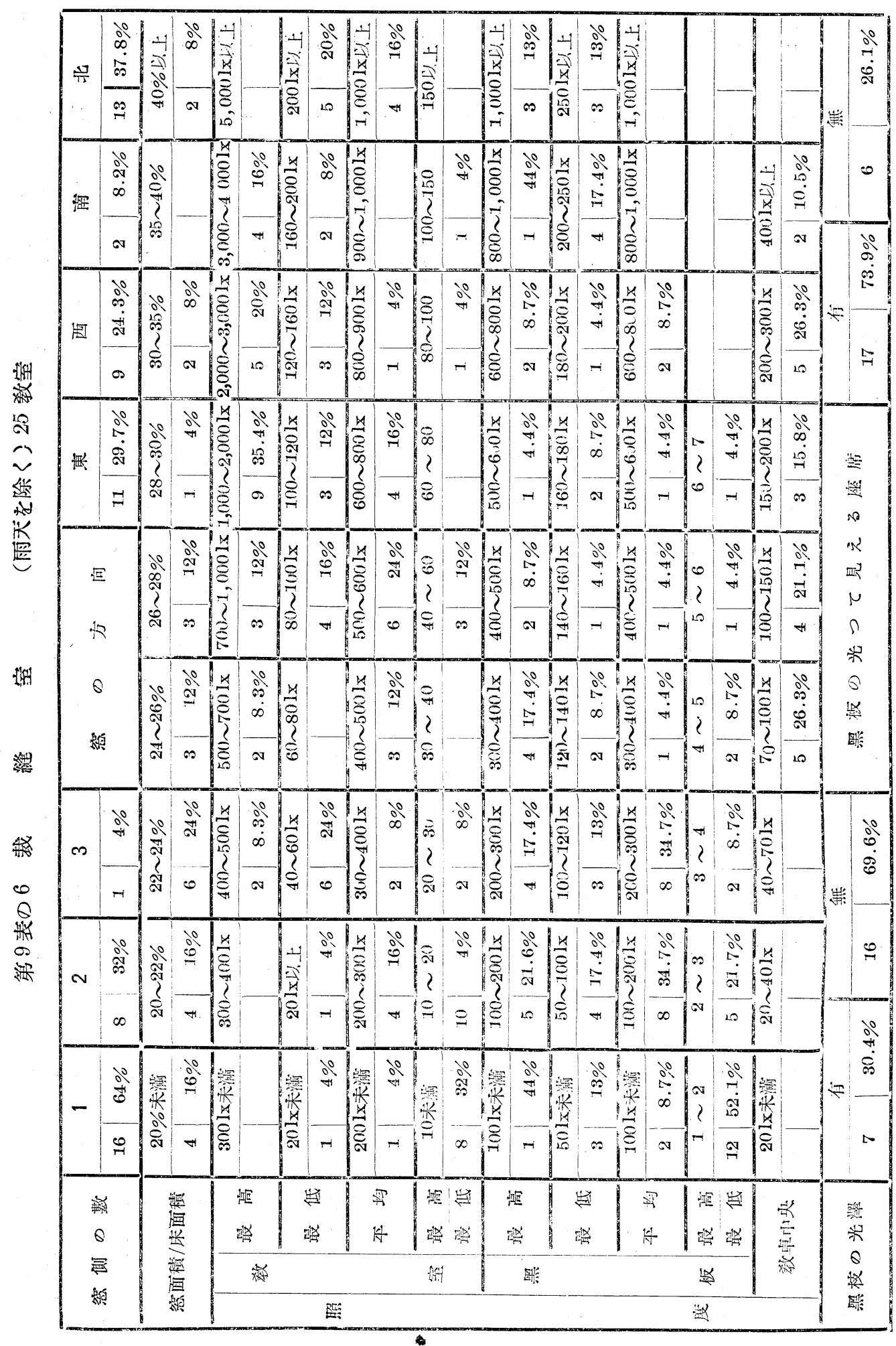




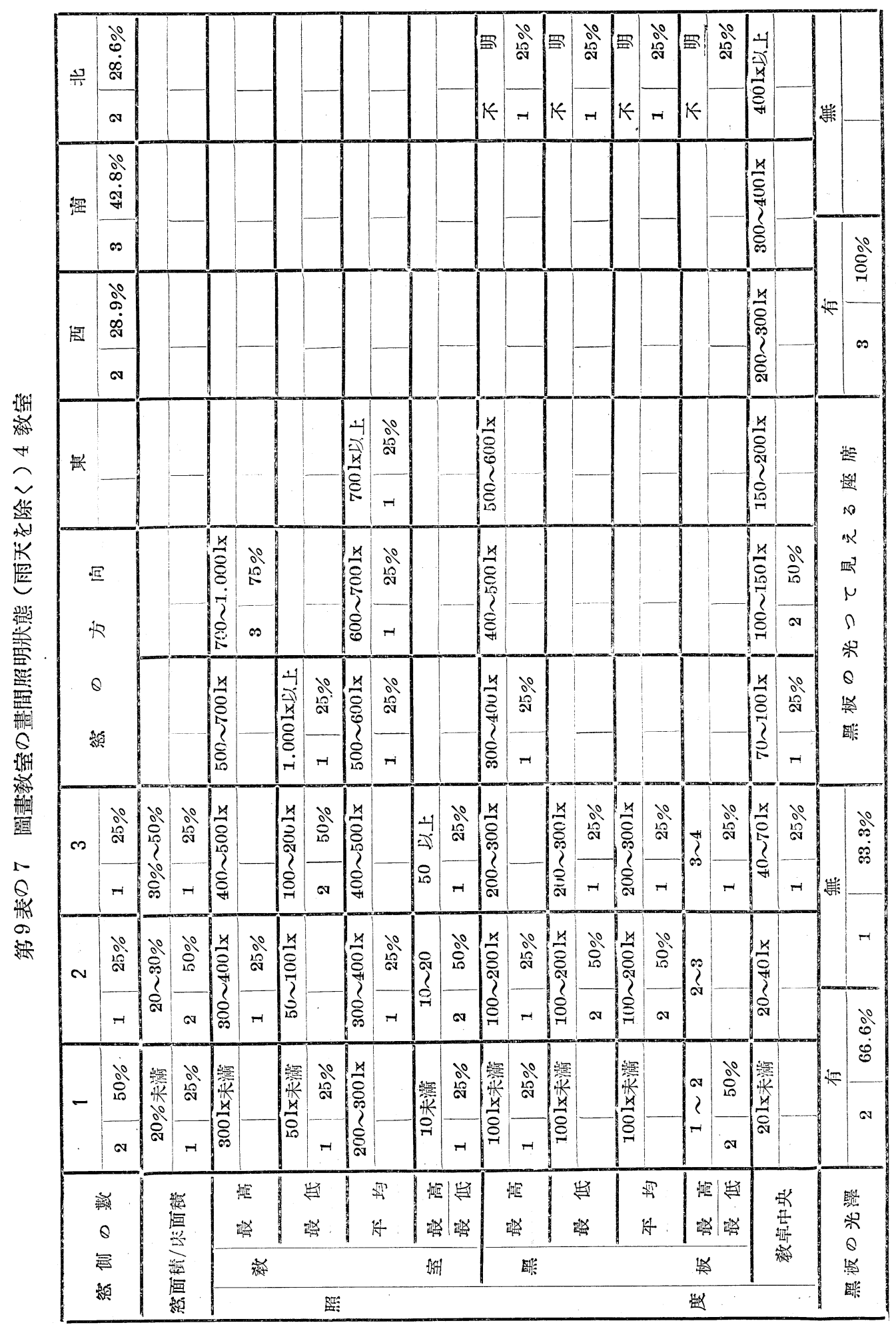




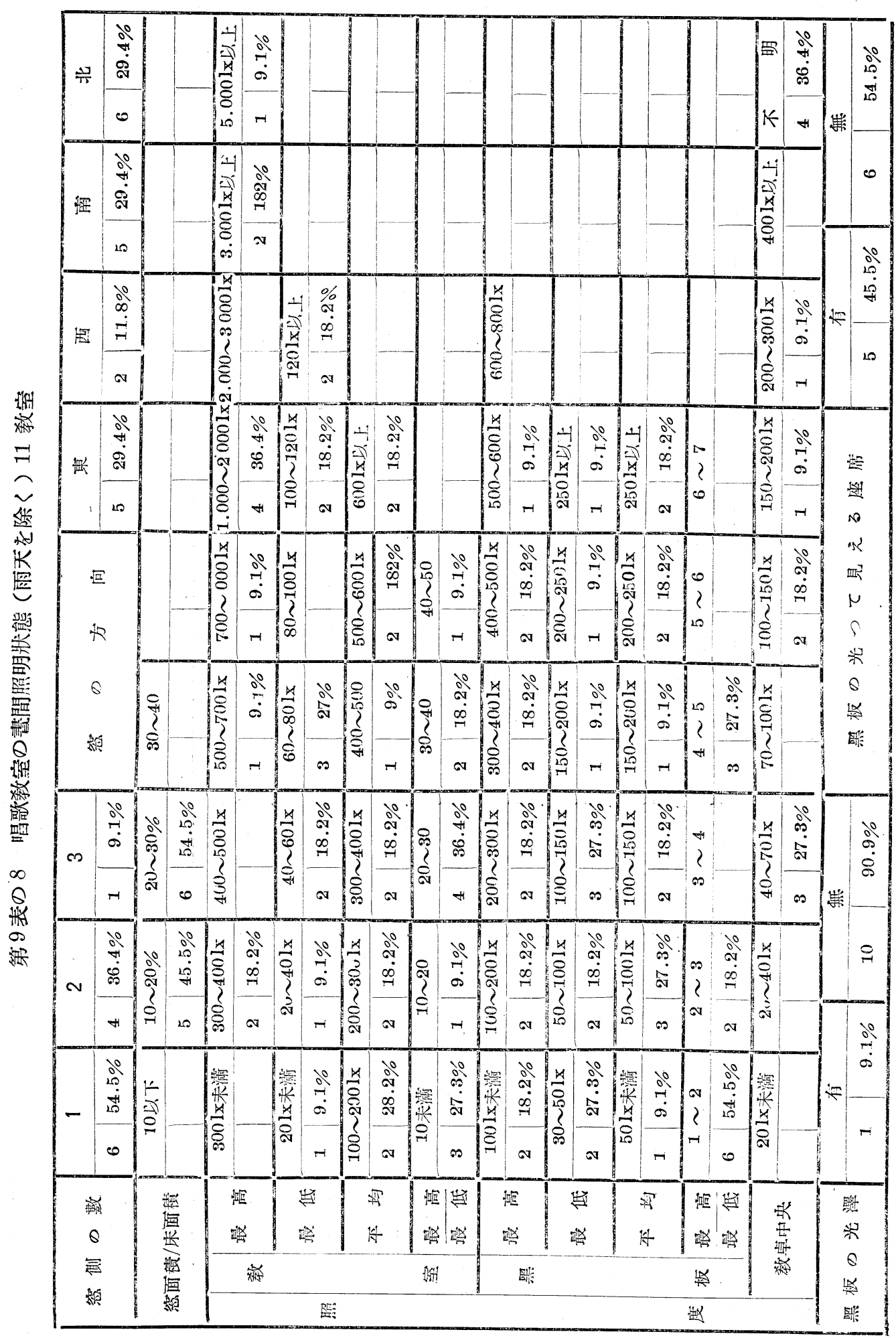




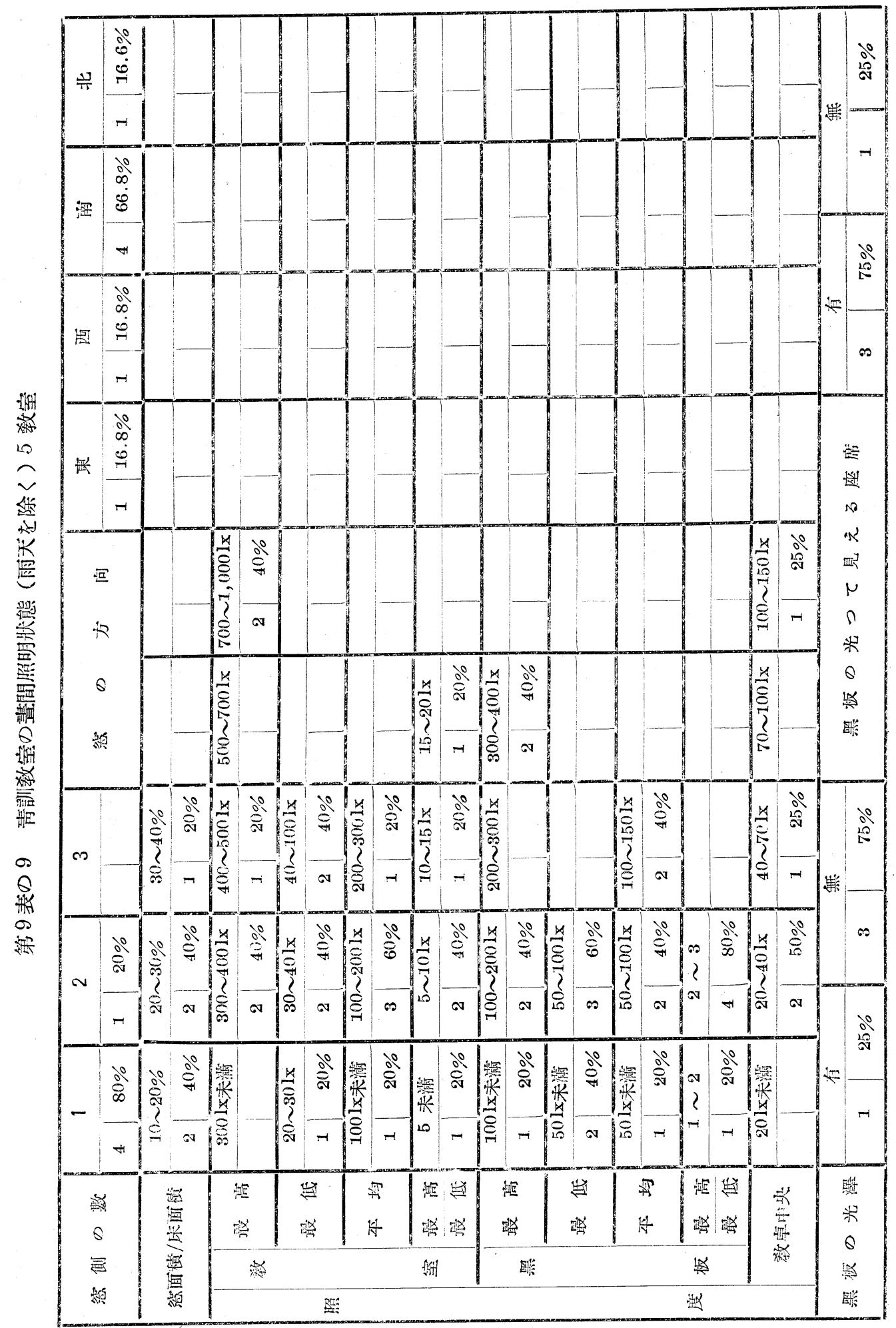



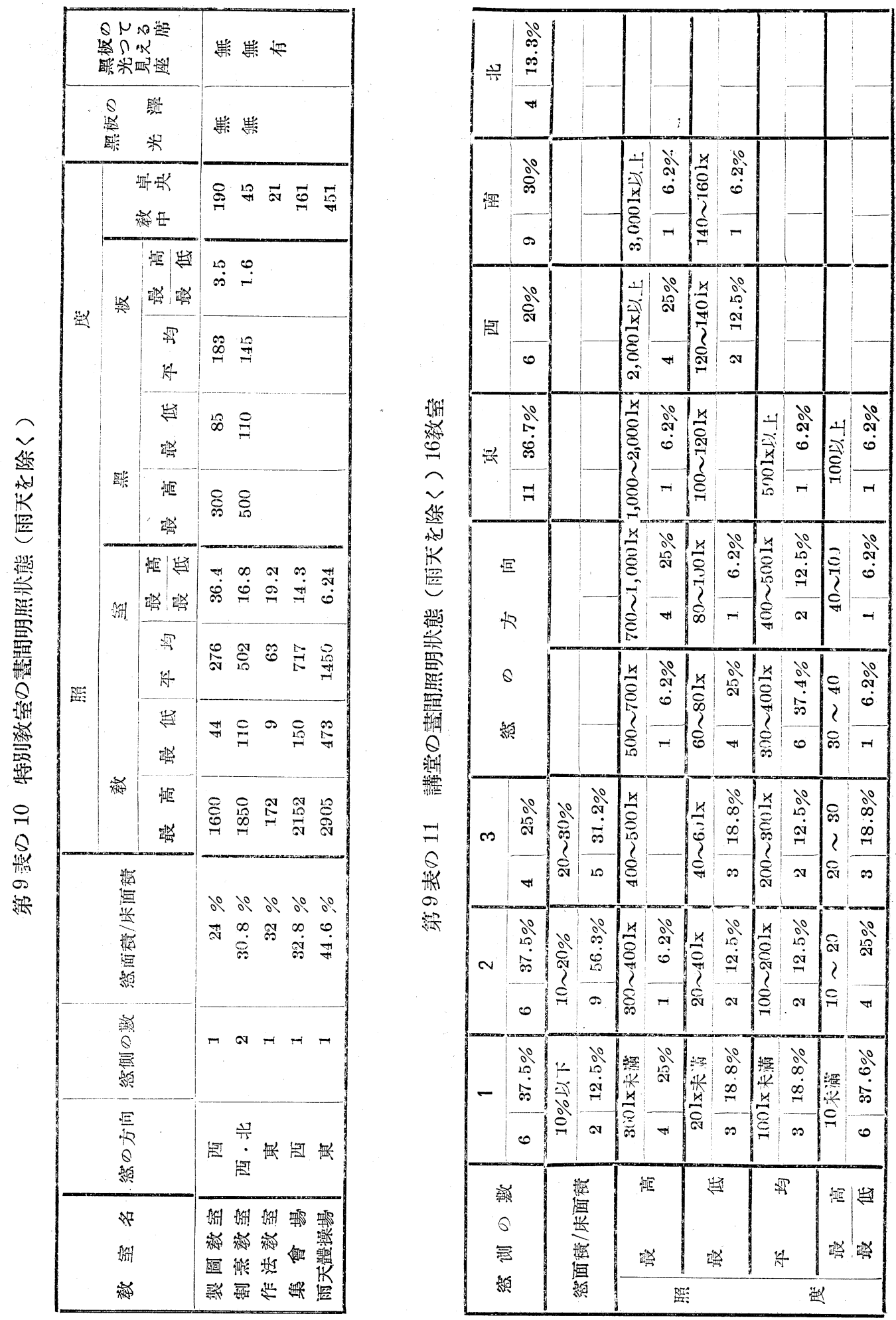


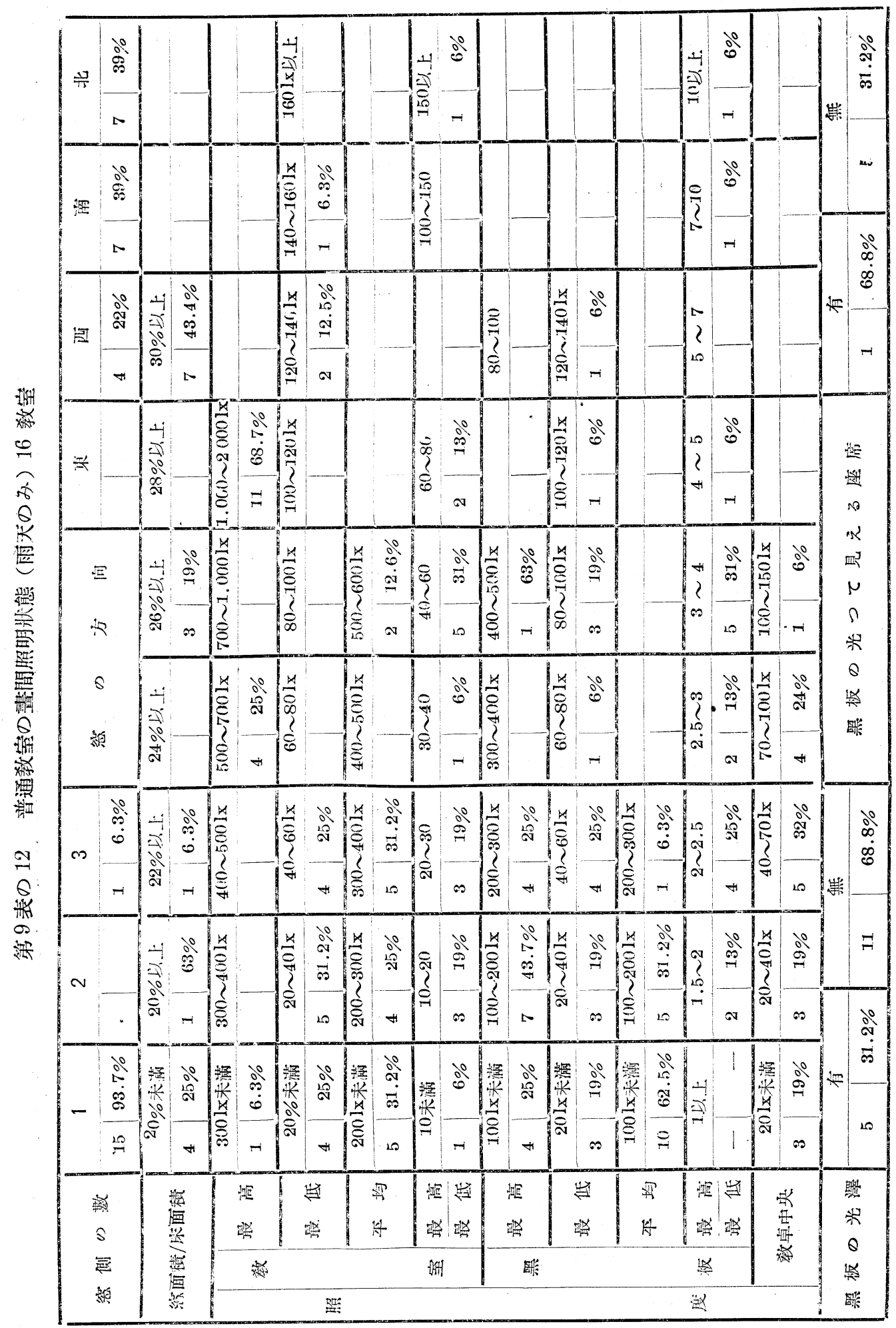



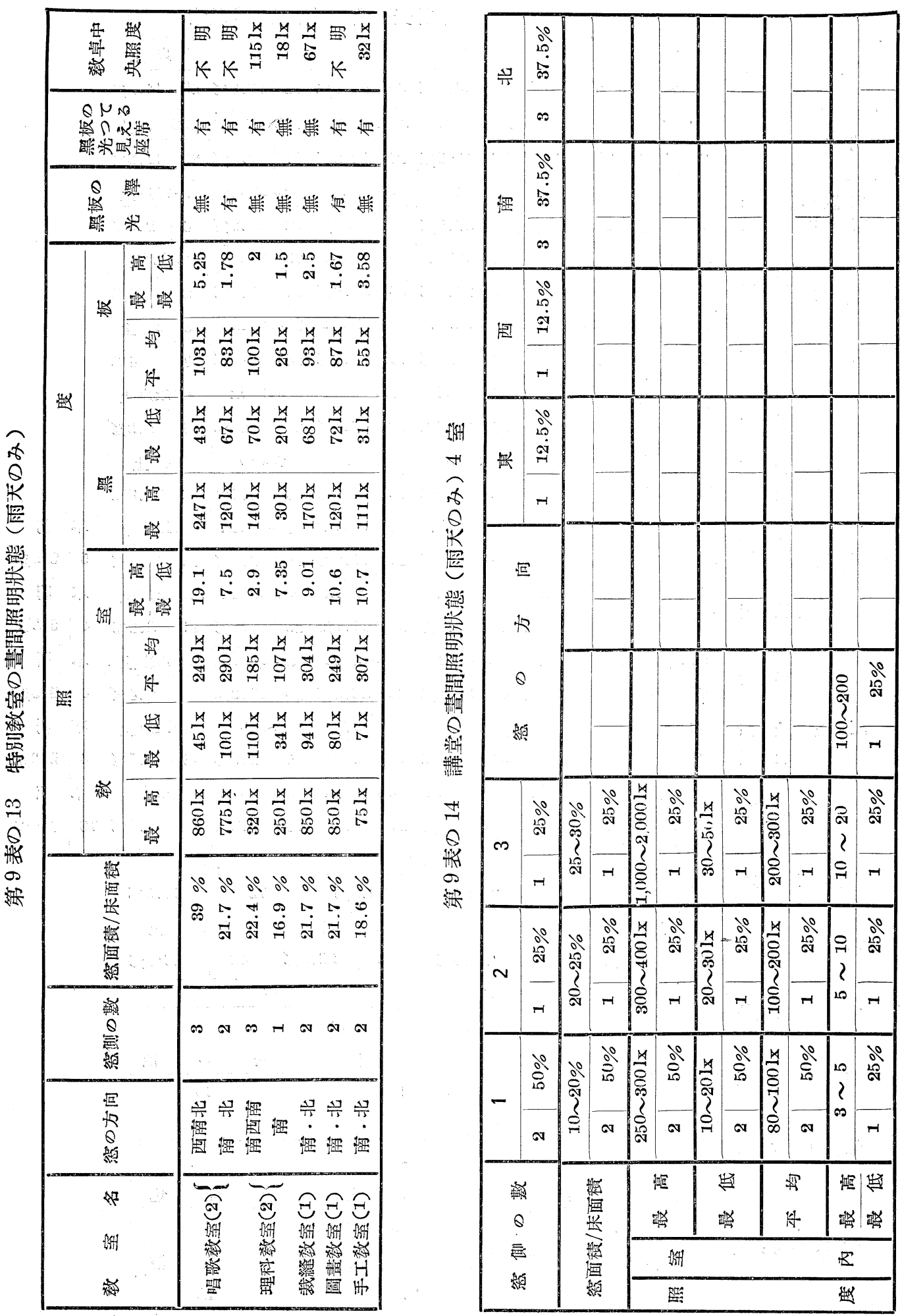
第 10 表の 1 夜間照明狀態集計表 測定敎室數 176 教室

\begin{tabular}{|c|c|c|c|c|c|c|c|c|c|c|c|c|c|c|c|}
\hline \multirow{2}{*}{ 燈 } & \multirow{2}{*}{\multicolumn{2}{|c|}{ 數 }} & \multicolumn{2}{|r|}{2} & \multicolumn{2}{|r|}{3} & \multicolumn{2}{|r|}{4} & \multicolumn{2}{|r|}{5} & \multicolumn{2}{|r|}{6} & \multicolumn{2}{|c|}{7 以上 } & \\
\hline & & & 5 & $2.9 \%$ & 6 & $3.4 \%$ & 25 & $14.2 \%$ & 43 & $24.4 \%$ & 72 & $40.9 \%$ & 25 & $14.2 \%$ & \\
\hline \multirow{2}{*}{\multicolumn{3}{|c|}{ 總ワツト數 }} & \multicolumn{4}{|c|}{$200 \mathrm{~W}$ 未滿 200 300W } & \multicolumn{2}{|c|}{$300 \sim 400 \mathrm{~W}$} & \multicolumn{2}{|c|}{$400 \sim 500 \mathrm{~W}$} & \multicolumn{4}{|c|}{$500 \sim 600 \mathrm{~W}$ 600W以上 } & \\
\hline & & & 8 & $4.5 \%$ & 25 & $20 \%$ & 72 & $40.9 \%$ & 24 & $13.6 \%$ & 17 & $9.7 \%$ & 20 & $11.3 \%$ & \\
\hline \multirow{2}{*}{\multicolumn{3}{|c|}{$\begin{array}{l}\text { 床面積 } 1 \text { 平方米 } \\
\text { 當りワット數 }\end{array}$}} & \multicolumn{2}{|c|}{$3 \mathrm{~W}$ 未霂 } & \multicolumn{2}{|c|}{$3 \sim 4 \mathrm{~W}$} & \multicolumn{2}{|c|}{$4 \sim 6 \mathrm{~W}$} & \multicolumn{2}{|c|}{$6 \sim 8 W$} & \multicolumn{2}{|c|}{$8 \sim 10 W$} & \multicolumn{2}{|c|}{ 10W以上 } & \\
\hline & & & 7 & $4 \%$ & 28 & $16 \%$ & 66 & $37.5 \%$ & 53 & $30 \%$ & 18 & $10.2 \%$ & 4 & $2.3 \%$ & \\
\hline \multirow{8}{*}{ 照 } & \multirow{4}{*}{ 教 } & & 301 & lx未萜 & & $\sim 401 x$ & & $\sim 501 x$ & & $\sim 701 x$ & $70 \sim$ & $2001 x$ & 100 & lx以上 & \\
\hline & & 最 高 & 37 & $21.6 \%$ & 43 & $24.4 \%$ & 43 & $24.4 \%$ & 34 & $18.8 \%$ & 11 & $6.3 \%$ & 8 & $4.5 \%$ & \\
\hline & & & 21 & 又沫滿 & & $\sim 51 x$ & & $-101 x$ & & $\sim 201 x$ & $20 \sim$ & $-301 x$ & $\overline{301}$ & $\overline{\mathrm{lx} \text { 以上 }}$ & \\
\hline & & 取 此 & 7 & $4 \%$ & 17 & $9.7 \%$ & 44 & $25 \%$ & 77 & $43.6 \%$ & 24 & $13.7 \%$ & 7 & $4 \%$ & \\
\hline & & 不 均 & $5 l_{2}$ & 沫洣 & $5 \sim$ & $-101 x$ & & $\sim 201 x$ & & $\sim 301 x$ & 30 - & $-501 x$ & 501 & lx以上 & \\
\hline & & 平均 & $\cdots$ & $\cdots$ & 8 & $4.5 \%$ & 54 & $30.7 \%$ & 68 & $38.5 \%$ & 35 & $20 \%$ & 11 & $6.3 \%$ & \\
\hline & 室 & 最 嵪 & & 未潖 & & $\sim 3$ & & $3 \sim 5$ & & $5 \sim 7$ & & $\sim 10$ & & 以.上 & \\
\hline & & 最 低 & 13 & $74 \%$ & 47 & $24.7 \%$ & 56 & $33.8 \%$ & 25 & $14.2 \%$ & 9 & $5.1 \%$ & 26 & $14.8 \%$ & \\
\hline & & & 20 & 1x未洮 & & $\sim 301 x$ & & $\sim 401 x$ & & $\sim 501 x$ & & $\sim 701 x$ & & lx以上 & 不 明 \\
\hline & 黑 & 取 高 & 33 & $18.7 \%$ & 48 & $27.4 \%$ & 39 & $22.1 \%$ & 21 & $11.9 \%$ & 12 & $6.8 \%$ & 18 & $10.2 \%$ & \begin{tabular}{l|l}
5 & $2.9 \%$
\end{tabular} \\
\hline & & & 21 & 又未滿 & & $\sim 51 x$ & & $2101 x$ & & $\sim 201 x$ & & $\sim 301 x$ & $\overline{301}$ & 1×以上 & 不 明 \\
\hline & & & 5 & $29 \%$ & 9 & $5.1 \%$ & 27 & $15.3 \%$ & 90 & $51.1 \%$ & 30 & $17 \%$ & 11 & $6.3 \%$ & 42.320 \\
\hline & & 不 & 51 & 又未灞 & $5 \sim$ & $101 x$ & & $\sim 201 x$ & & $\sim 301 x$ & & $\sim 501 x$ & 501 & X以上 & 不 明 \\
\hline & & & 7 & $4 \%$ & 11 & $6.3 \%$ & 57 & $32.4 \%$ & 64 & $36.3 \%$ & 20 & $11.3 \%$ & 13 & $7.4 \%$ & \begin{tabular}{l|l}
4 & $2.3 \%$
\end{tabular} \\
\hline 度 & 板 & 最 高 & & 末萠 & & 23 & & $3 \sim 5$ & & $5 \sim 7$ & & $\sim 10$ & 101 & 1x以上 & 不 明 \\
\hline & & 最 低 & 68 & $38.6 \%$ & 36 & $20.4 \%$ & 37 & $21 \%$ & 11 & $6.3 \%$ & 5 & $2.9 \%$ & 15 & $8.5 \%$ & $42.3 \%$ \\
\hline & & 卢中央 & 10 & lx未涩 & 10 & $2201 x$ & & $\sim 301 x$ & & $\sim 501 x$ & 50 & $\sim 801 x$ & 801 & 1x以上 & 不 明 \\
\hline & & $F$ & 20 & $11.3 \%$ & 48 & $27.4 \%$ & 43 & $24.4 \%$ & 27 & $15.7 \%$ & 13 & $7.2 \%$ & 12 & $6.8 \%$ & \begin{tabular}{l|l|}
13 & $7.2 \%$ \\
\end{tabular} \\
\hline & & & & & & & & 有 & 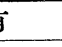 & & & 無 & & & \\
\hline & 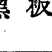 & 光 & 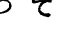 & 見元 & る & 席 & & 94 & & $6.5 \%$ & & 72 & & $3.5 \%$ & \\
\hline 雷 & & & & $\mathrm{V}$ 未溜 & & & $\mathrm{VD}$ & V.上 & & 100V以 & & & 4V以 & & \\
\hline & & & 14 & 8 & $\%$ & 50 & & $8.4 \%$ & 65 & 36 . & $9 \%$ & 48 & & $3 \%$ & \\
\hline 電 & 怓 等 & 日 & & グ & 口 & - & ブ & & & & 笠 & 笠 & & & \\
\hline 电 & 8.5 & 然 & & 76 & & & & & & 102 & & & & & \\
\hline & & 刑 & & $\mathrm{P} .1$ & & & & 椀 & & 型 & & そ & $D$ & 他 & \\
\hline & & 䅅。 & & 92 & & & & & 2 & & & 10 & 0 & & \\
\hline & D & 材 啠 & & 乳 色 & 硝 & 子 & & 金 & & 屬 & & & & & \\
\hline & W & 财 負 & & 10 & & & & & 1 & & & & & & \\
\hline & & & & 眞 & & 空 & & 瓦 & 政 & 入 & & 光 & & 色 & \\
\hline & Fif 20 & 理 & & 32 & & & & & 143 & & & 1 & & & \\
\hline 电? & H & 性知 & & 透 & & 明 & & 䠛 & & 消 & & 䍂 & & 消 & \\
\hline & & & & 89 & & & & & 77 & & & 21 & 1 & & \\
\hline
\end{tabular}


第 10 表つ 2 普通敉室の夜間照明狀態(107 敎室)

\begin{tabular}{|c|c|c|c|c|c|c|c|c|c|c|c|c|c|c|c|}
\hline \multirow{2}{*}{ 䗳 } & & & \multirow{2}{*}{ 数就 } & \multicolumn{2}{|r|}{2} & \multicolumn{2}{|r|}{3} & \multicolumn{2}{|r|}{4} & \multicolumn{2}{|r|}{5} & \multicolumn{2}{|r|}{6} & \multicolumn{2}{|c|}{7 以上 } \\
\hline & & & & 2 & $1.9 \%$ & 3 & $2.8 \%$ & 16 & $15 \%$ & 32 & $29.7 \%$ & 48 & $45 \%$ & 6 & $5.5 \%$ \\
\hline \multirow{2}{*}{ 總 } & \multirow{2}{*}{ ワ } & \multirow{2}{*}{ " } & \multirow{2}{*}{ 下 } & \multicolumn{2}{|c|}{$200 \mathrm{~T}$ 未满 } & \multicolumn{2}{|c|}{$200 \sim 300 \mathrm{~W}$} & \multicolumn{2}{|c|}{$300 \sim 409 \mathrm{~W}$} & \multicolumn{2}{|c|}{$400 \sim 500 \mathrm{~W}$} & \multicolumn{2}{|c|}{$500 \sim 600 \mathrm{~W}$} & \multicolumn{2}{|c|}{$600 \mathrm{WD}$ 上 } \\
\hline & & & & 5 & $4.7 \%$ & 28 & $26 \%$ & 50 & $47 \%$ & 12 & $11 \%$ & 7 & $6.6 \%$ & 5 & $4.7 \%$ \\
\hline \multirow{2}{*}{\multicolumn{4}{|c|}{$\begin{array}{l}\text { 林面積 } 1 \text { 本方米 } \\
\text { 當りワット數 }\end{array}$}} & \multicolumn{2}{|c|}{$3 n$ 未槜 } & 3 & $\sim 4 W$ & & $\sim 6 \mathrm{~W}$ & & $\sim 8 W$ & & $\sim 10 \mathrm{~W}$ & & W以上 \\
\hline & & & & 5 & $4.7 \%$ & 17 & $16 \%$ & 39 & $36 \%$ & 35 & $33 \%$ & 9 & $8.4 \%$ & 2 & $1.9 \%$ \\
\hline & & & & & 沫萠 & & $2401 x$ & & $2501 x$ & & $\sim 701 x$ & & $2100 \mathrm{~lx}$ & & OIxD上 \\
\hline & 呚 & 掫 & 㬏 & 19 & $17.7 \%$ & & $19.6 \%$ & 31 & $29 \%$ & 24 & $22.4 \%$ & 7 & $6.6 \%$ & 5 & $4.7 \%$ \\
\hline & & & & & 区未瀛 & & $251 x$ & & $\sim 101 x$ & & $\sim 201 x$ & & $\sim 301 x$ & & lx.上. \\
\hline 照 & & 取 & 4 & 2 & $1.9 \%$ & 11. & $10 \%$ & 24 & $22.4 \%$ & 49 & $46 \%$ & 16 & $15 \%$ & 5 & $4.7 \%$ \\
\hline & & & & & |x未灌 & & $2101 x$ & & $\sim 201 x$ & & $\sim 301 x$ & & $\sim 501 x$ & & 1X以上 \\
\hline & & & 侍 & & & 5 & $4.7 \%$ & 29 & $27.1 \%$ & 42 & $39.3 \%$ & 26 & 24.2 & 5 & $4.7 \%$ \\
\hline & 室 & 最 & 高 & & 未满 & & $\sim 3$ & & $\sim 5$ & 5 & $\sim 7$ & & $7 \sim 10$ & & OD.上 \\
\hline & & 最 & 低 & 8 & $7.5 \%$ & 27 & $25 \%$ & 36 & $34 \%$ & 17 & $16 \%$ & 7 & $6.5 \%$ & 12 & $11 \%$ \\
\hline & & & & & $\mathrm{x}$ 忞灌 & 20 & $-301 x$ & & $\sim 401 \mathrm{x}$ & & $2501 x$ & & $\sim 701 x$ & & 1x以上 \\
\hline & 黑 & 取 & {$[i]$} & 21. & $20 \%$ & & $29 \%$ & 22 & $20.1 \%$ & & $12.1 \%$ & 8 & $7.5 \%$ & 12 & $11.3 \%$ \\
\hline & & & & & x未灌 & & $\sqrt{5} \mathrm{~lx}$ & & $\sim 101 x$ & & $\sim 201 x$ & & $\sim 301 x$ & & X以上 \\
\hline & & & & 2 & $1.9 \%$ & 8 & $7.5 \%$ & 18 & $16.8 \%$ & 51 & $47.6 \%$ & 19 & $17.8 \%$ & 9 & $8.4 \%$ \\
\hline & & & & & 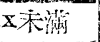 & & $-101 x$ & & $\sim 201 x$ & & $\sim 301 x$ & & $\sim 501 x$ & & 1x以上 \\
\hline & & 4 & $I=-$ & 6 & $5.5 \%$ & 6 & $5.5 \%$ & 37 & $34.6 \%$ & 34 & $31.9 \%$ & 17 & $16 \%$ & 7 & $6.5 \%$ \\
\hline 度 & 板 & 最 & & & 来溜 & 2 & $\sim 3$ & & $\sim 5$ & 5 & $\sim 7$ & & $\sim 10$ & & O以.上 \\
\hline & & 鼠 & & 52 & 48 & 20 & 19 & 21 & 20 & 5 & $4.7 \%$ & 3 & $2.8 \%$ & 6 & $5.5 \%$ \\
\hline & & & & & $\mathrm{lx}$ 来䔕 & 10 & $201 x$ & & $\sim 301 x$ & & $\sim 501 x$ & & $2801 \mathrm{x}$ & & 1X以上 \\
\hline & & 旨 & & 11 & $10 \%$ & 33 & $31 \%$ & 29 & $27.1 \%$ & 17 & $16 \%$ & 9 & $84 \%$ & 8 & $7.5 \%$ \\
\hline & & & & & & & & & & & & & & & \\
\hline 黑 & 板 & U & 光 & D & 見 & -3 & 座 席 & & 67 & & $67 \%$ & & 33 & & $33 \%$ \\
\hline & & & & & $96 \mathrm{~V}$ 禾洣 & & & VD & & & $100 \mathrm{~V}$. & & & W超 & \\
\hline 电 & & & 武 & & 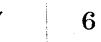 & $6 \%$ & 32 & & $29.7 \%$ & 3 & 7 & & 31 & & $28.9 \%$ \\
\hline & & & & & グ & 口 & - & & プ & & & & 籊 & & \\
\hline 䉓 & 部 & 焀 & 其 & & & & & $32 \%$ & & & 73 & & & 68 & \\
\hline & & & & & $\bar{P}$ & 1 & & & 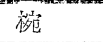 & & 型 & & 其 & & 他。 \\
\hline $2 i f$ & & $\infty$ & & & & 88 & & & & & & & 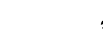 & & \\
\hline & & & & & 乳 色 & 硝 & $J$ & & 金 & & 虽 & & & & \\
\hline & の & 材 & & & & 2 & & & & 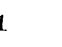 & & & & & \\
\hline & & & & & 旨 & & 空 & & 瓦 & 4 & 入 & & 琶: & & 光 \\
\hline & & & & & & 23 & & & & 87 & & & & & \\
\hline & Is & (5) & & & 透 & & 明 & & 㦛 & & 沙 & & 4 & & 消 \\
\hline & & & & & & & & & & 52 & & & & 6 & \\
\hline
\end{tabular}


第 10 表つ3 理科教室つ夜間热明状熊（15敉室）

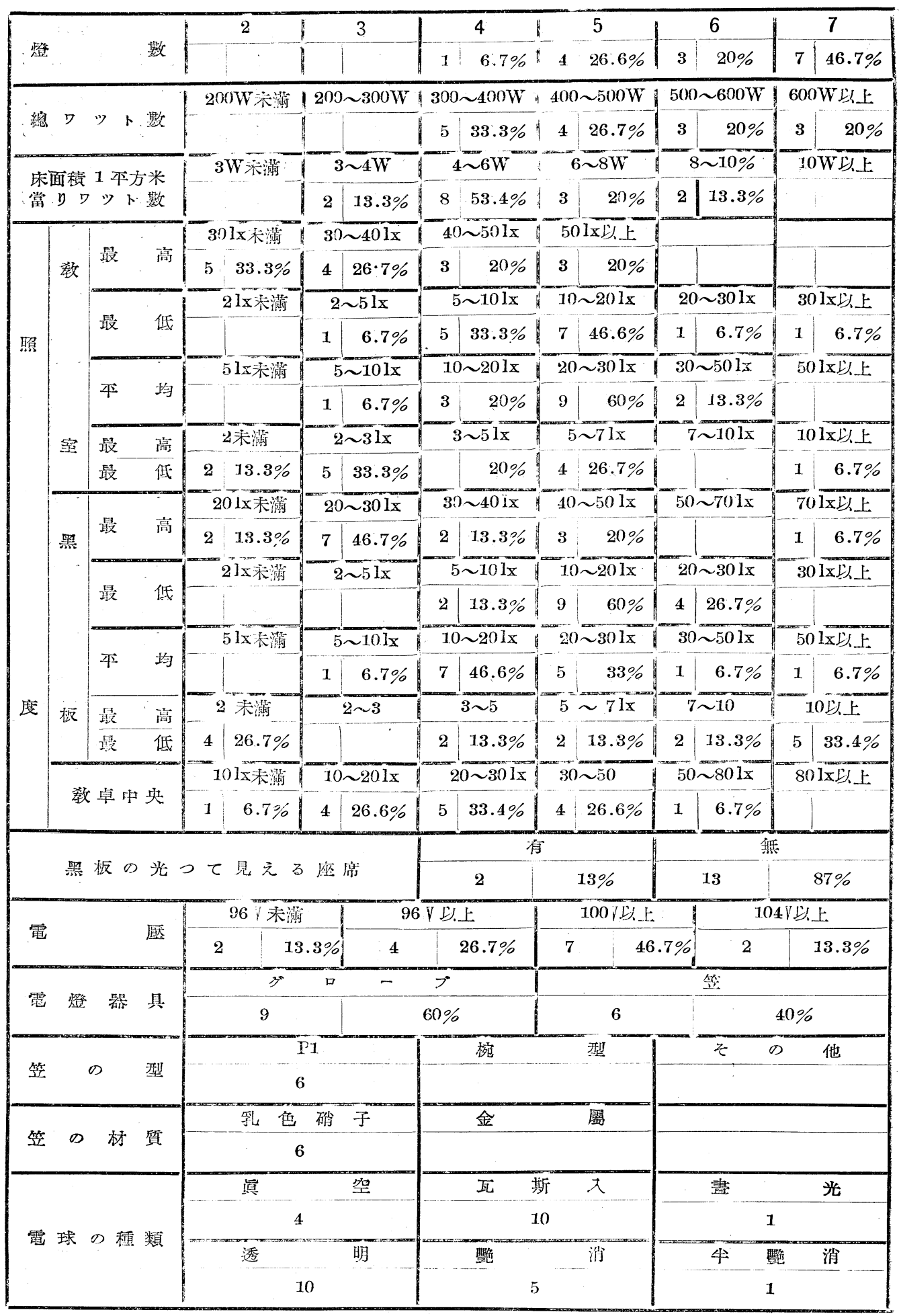


第10表の 4 地歴呚室の夜間㷛明狀態（3 呚室）

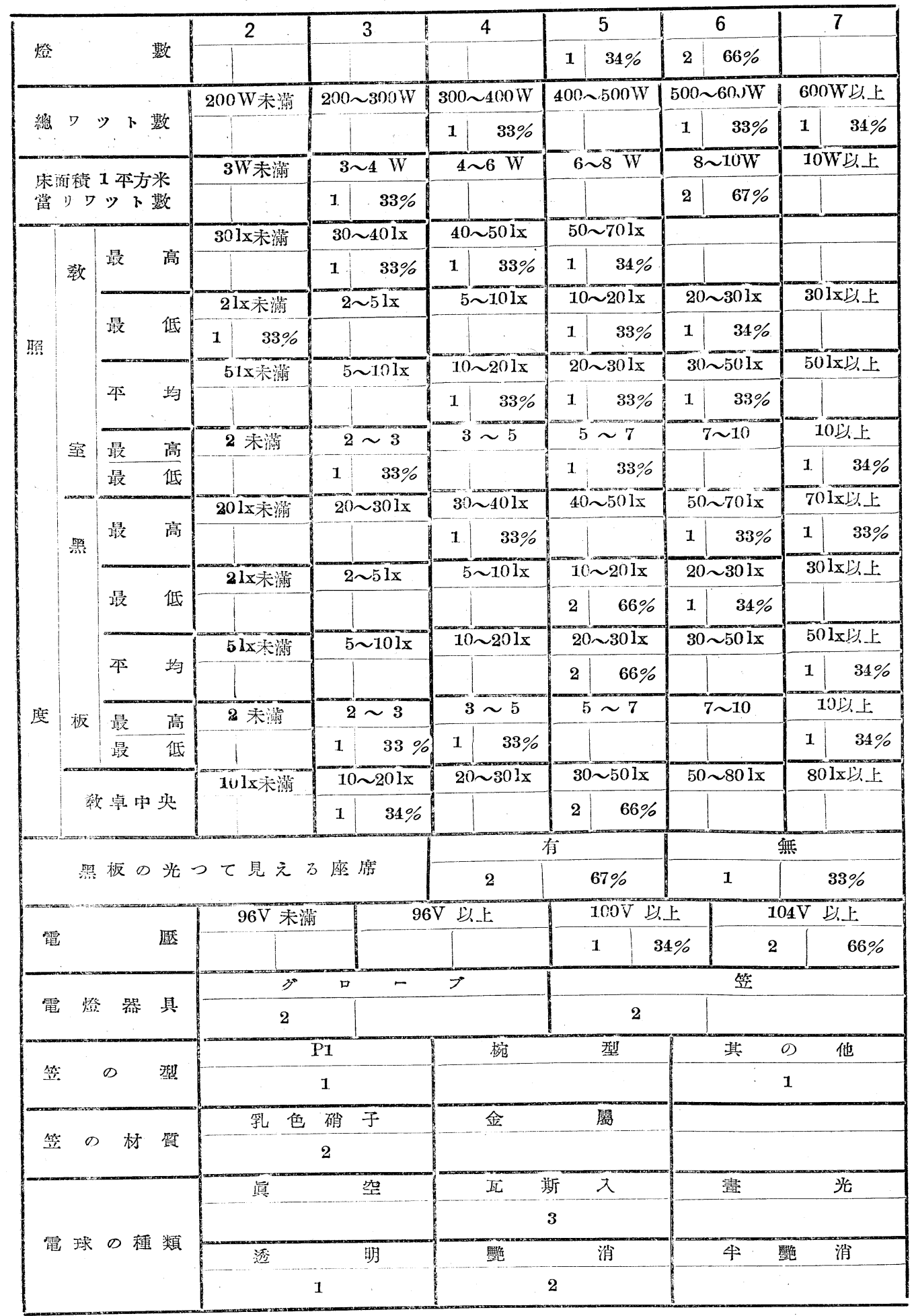




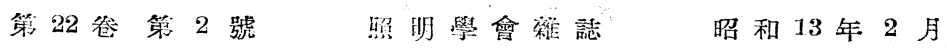

第 10 表の 5 手工呚臺の夜間照明狀態 (6 敎室)

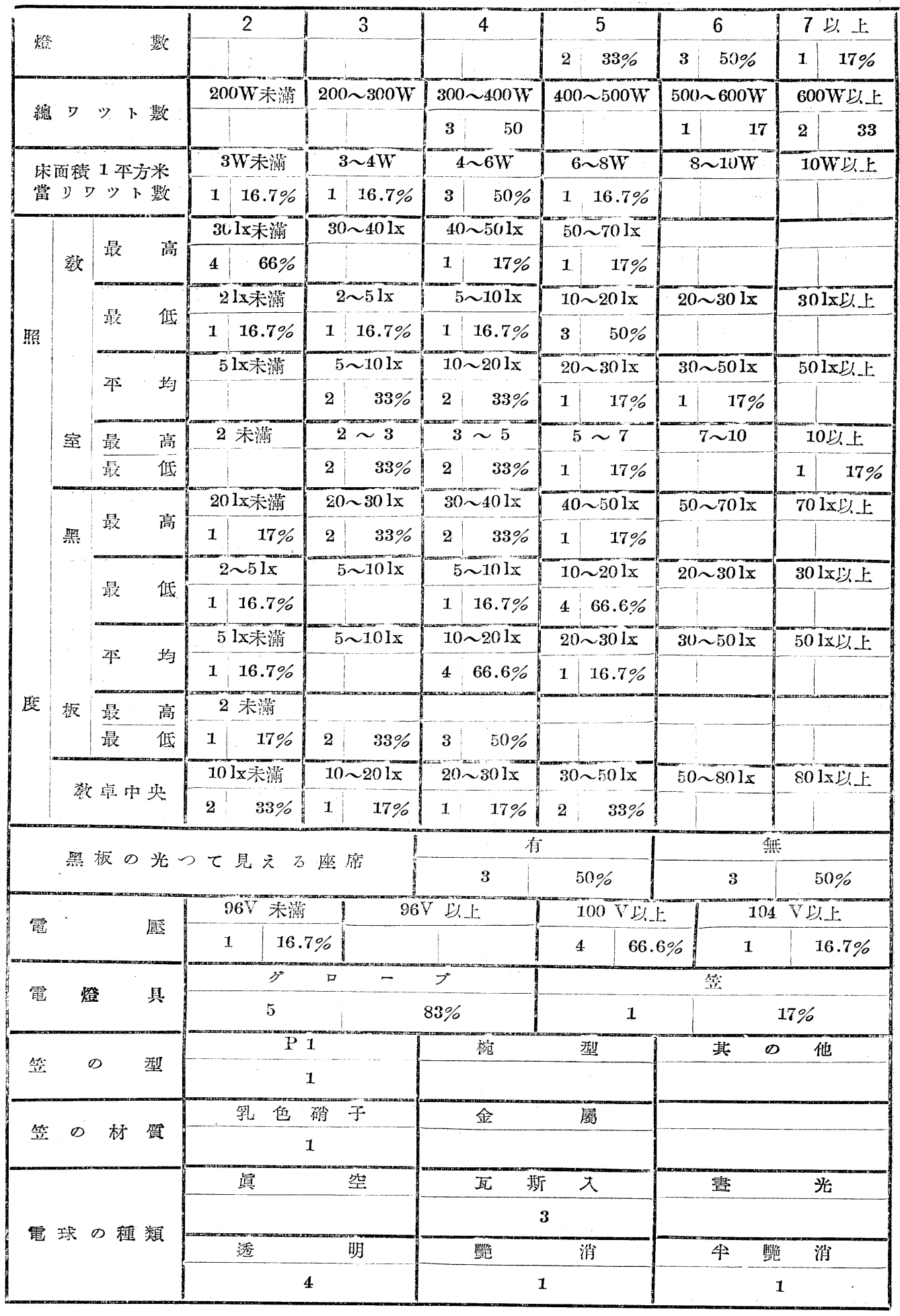




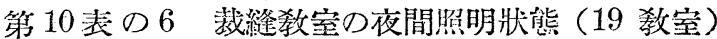

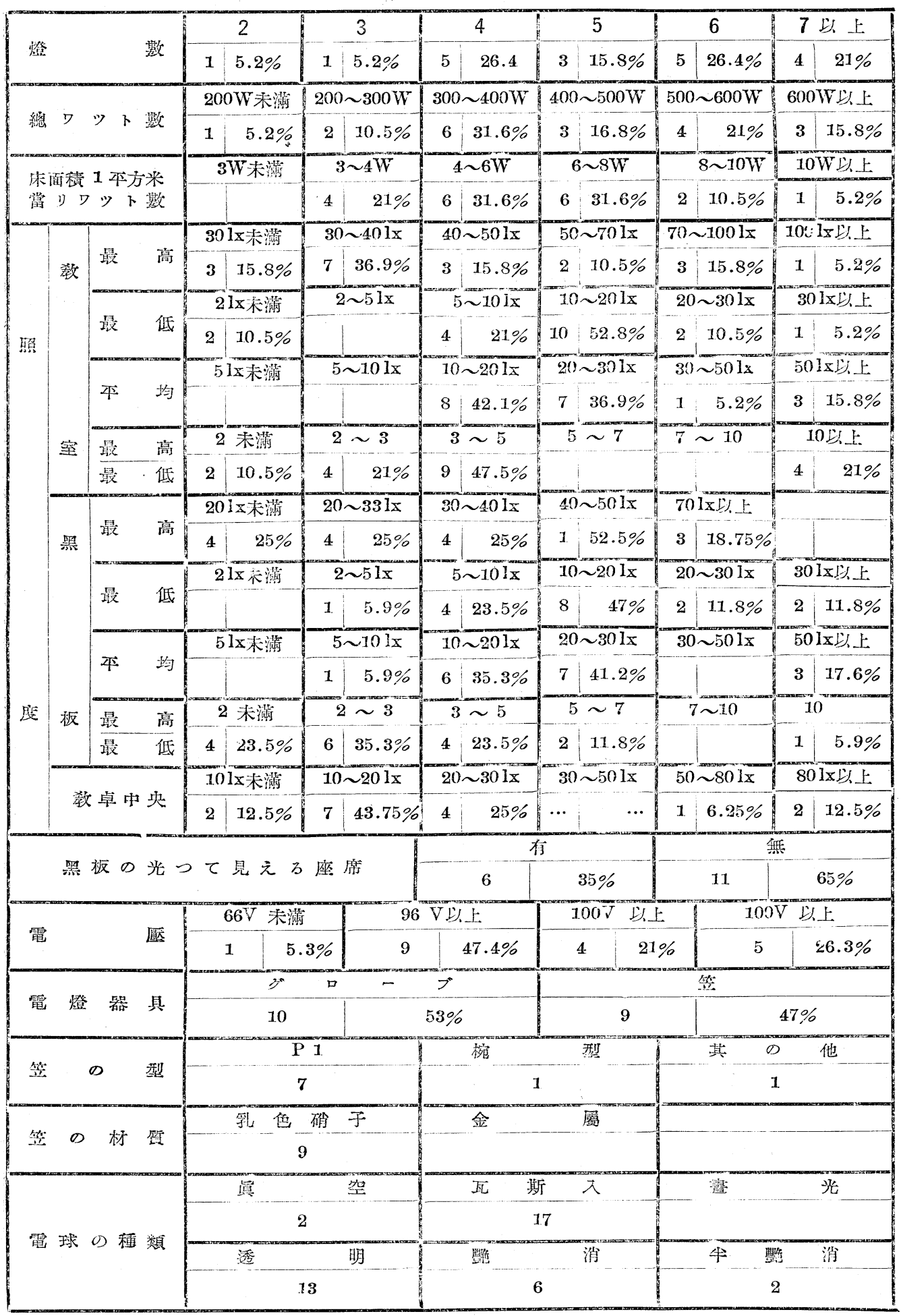


第 10 表の 7 圖畫敎堂の夜間照明狀態 (5 敉室)

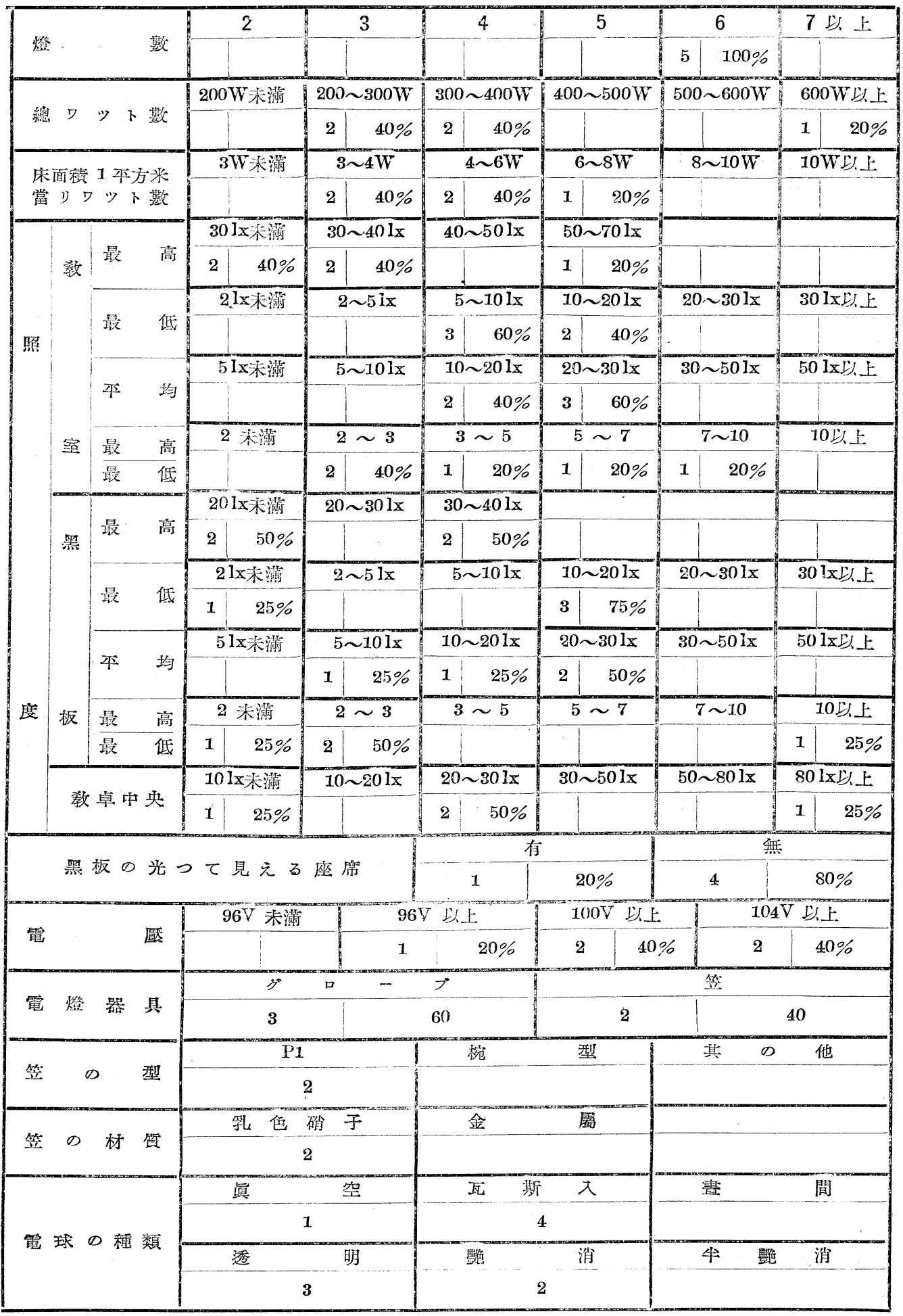


第 10 表の 8 唱歌敉室の夜間照明狀態 (12 敘室)

\begin{tabular}{|c|c|c|c|c|c|c|c|c|c|c|c|c|c|c|}
\hline \multirow{2}{*}{ 燈 } & \multirow{2}{*}{\multicolumn{2}{|c|}{ 數 }} & \multicolumn{2}{|c|}{2} & \multicolumn{2}{|c|}{3} & \multicolumn{2}{|c|}{4} & \multicolumn{2}{|c|}{5} & \multicolumn{2}{|c|}{6} & \multicolumn{2}{|r|}{7} \\
\hline & & & 1 & $8 \%$ & & & 2 & $17 \%$ & 1 & $8 \%$ & 5 & $42 \%$ & 3 & $25 \%$ \\
\hline \multirow{2}{*}{ 總 } & \multirow{2}{*}{ ர } & \multirow{2}{*}{ ツト数 } & \multicolumn{2}{|c|}{ 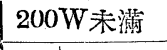 } & \multicolumn{2}{|c|}{$200 \sim 300 W$} & \multicolumn{2}{|c|}{$300 \sim 400 \mathrm{~W}$} & \multicolumn{2}{|c|}{$400 \sim 500 \mathrm{~W}$} & \multicolumn{2}{|c|}{$500 \sim 600 \mathrm{~W}$} & \multicolumn{2}{|c|}{ 600W以上 } \\
\hline & & & 1 & $8 \%$ & 1 & $8 \%$ & 4 & $34 \%$ & 2 & $17 \%$ & 1 & $8 \%$ & 3 & $25 \%$ \\
\hline \multirow{2}{*}{\multicolumn{3}{|c|}{$\begin{array}{l}\text { 床面積 } 1 \text { 本方米 } \\
\text { 當リワット數 }\end{array}$}} & \multicolumn{2}{|c|}{ 3W未混 } & \multicolumn{2}{|c|}{$3 \sim 4 W$} & \multicolumn{2}{|c|}{$4 \sim 6 \mathrm{~W}$} & \multicolumn{2}{|c|}{$6 \sim 8 W$} & \multicolumn{2}{|c|}{$8 \sim 10 \mathrm{~W}$} & & W以上 \\
\hline & & & & & 1 & $8 \%$ & 4 & $34 \%$ & 6 & $50 \%$ & & & 1. & 8 \\
\hline & & & & 未混 & & $-41 x$ & & $-501 x$ & & $701 x$ & 70 & $1001 x$ & $\sqrt{100}$ & 双上 \\
\hline & 数 & 最 & 2 & $17 \%$ & 6 & $50 \%$ & 3 & $25 \%$ & & & 1 & $8 \%$ & & \\
\hline & & & & 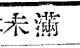 & & $-51 x$ & & $-101 x$ & & $201 x$ & & $\longdiv { 2 0 1 x }$ & & X以.上 \\
\hline 照 & & 低 & & & 2 & $17 \%$ & 5 & $41 \%$ & 3 & $25 \%$ & 2 & $17 \%$ & & \\
\hline & & & & 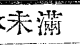 & & $-101 x$ & & $201 x$ & & $.301 x$ & & $\sim 501 x$ & & 1x以上 \\
\hline & & 均 & & & & & 5 & $42 \%$ & 3 & $25 \%$ & 3 & $25 \%$ & 1 & $8 \%$ \\
\hline & 窒 & 最高 & & 茳 & & $\sim 3$ & 5 & $\sim 5$ & & $\sim 7$ & & $7 \sim 10$ & & 以上 \\
\hline & & 最 低 & & & 1 & $34 \%$ & 5 & $41 \%$ & & & 1 & $8 \%$ & 2 & $17 \%$ \\
\hline & & & & 来淽 & & $-301 x$ & & $\sim 401 x$ & & $-501 x$ & & $\sim 701 x$ & 100 & 1区以上 \\
\hline & 黑 & 最 & 1 & $25 \%$ & 1 & $8 \%$ & 4 & $34 \%$ & 2 & $17 \%$ & 1 & $8 \%$ & 1 & $8 \%$ \\
\hline & & & & 妹满 & & $\sim 51 x$ & & $\sim 701 x$ & & $\sim 201 x$ & & $\sim 301 x$ & & 1x以上 \\
\hline & & 偨 & 1 & $8 \%$ & & & 1 & $8 \%$ & 7 & $59 \%$ & 3 & $25 \%$ & & \\
\hline & & & & 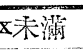 & & $\sim 101 x$ & & $\sim 201 x$ & & $\sim 301 x$ & & $\sim 501 x$ & & 1x以.上 \\
\hline & & 本均 & & & & & 1 & $8 \%$ & 8 & $67 \%$ & & & 1 & $8 \%$ \\
\hline 度 & 板 & 最商 & & 未潔 & & $23 x$ & & $\sim 5$ & & $\sim 7$ & & $7 \sim 10$ & 1 & O以.上 \\
\hline & & 最低 & 4 & $83 \%$ & 3 & $25 \%$ & 2 & $17 \%$ & 2 & $17 \%$ & & & 1 & $8 \%$ \\
\hline & & xht & & 沫满 & & $\sim 201 x$ & & $\sim 301 x$ & & $\sim 501 x$ & & $1 \sim 801 x$ & 80 & 1x以上 \\
\hline & & a & 2 & & 1 & & & & 1 & & & & & \\
\hline & & & & & & & & & & & & & 焎 & \\
\hline & & 极 $の$ 光 & $c$ & 見え & 万 座 & & & 9 & & $75 \%$ & & 3 & & $25 \%$ \\
\hline 雨 & & & & $96 \mathrm{~V}$ 未 & & & $6 \mathrm{~V}$ & & & $100 \mathrm{~V}$. & & & $04 \mathrm{VD}$ & .上 \\
\hline 䉓 & &. & & & $17 \%$ & 3 & & $25 \%$ & & 5 & $41 \%$ & 2 & & $17 \%$ \\
\hline & 15 & 然 哭 & & 30 & 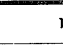 & - & 7 & & & & & 笠 & & \\
\hline & 4 & 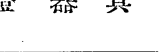 & & 9 & & & & & & 4 & & & & \\
\hline & & FII & & & P 1 & & 1 & 椀 & & 型 & & 其 & の & 他 \\
\hline & & 㷱 & & & 2 & & & & & & & & 3 & \\
\hline & $\theta$ & 新 & & 缽 角 & 硝 & 子 & & 金 & & 屬 & & & & \\
\hline & $\therefore 0$ & D 领 筫 & & & 4 & & & & & & & & & \\
\hline & & & & 萨 & & 空 & & 瓦 & 斯 & 入 & & 青: & & 光 \\
\hline & & & & & 1 & & & & 11 & & & & & . \\
\hline & 球 & の種 類 & & 透 & & 明 & & 㒥 & & 游 & & 乎 & 邫绖 & 消 \\
\hline & & & & & 8 & & & & 5 & & & & & \\
\hline
\end{tabular}


第 10 表の 9 毒訓㸚室の夜間照明狀態（5 敉室）

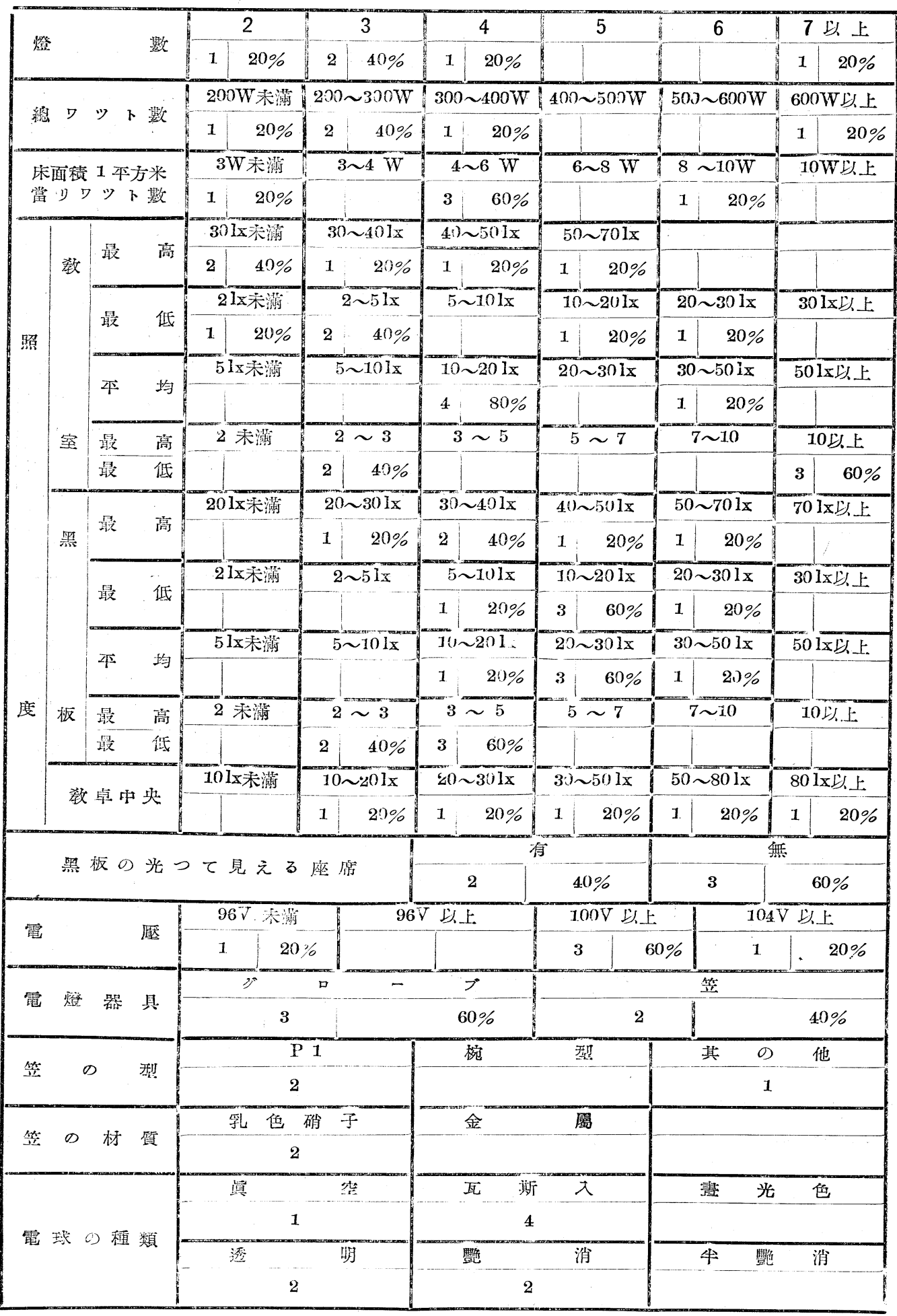


第 10 表の 10 講堂の夜間照明狀態（14 室）

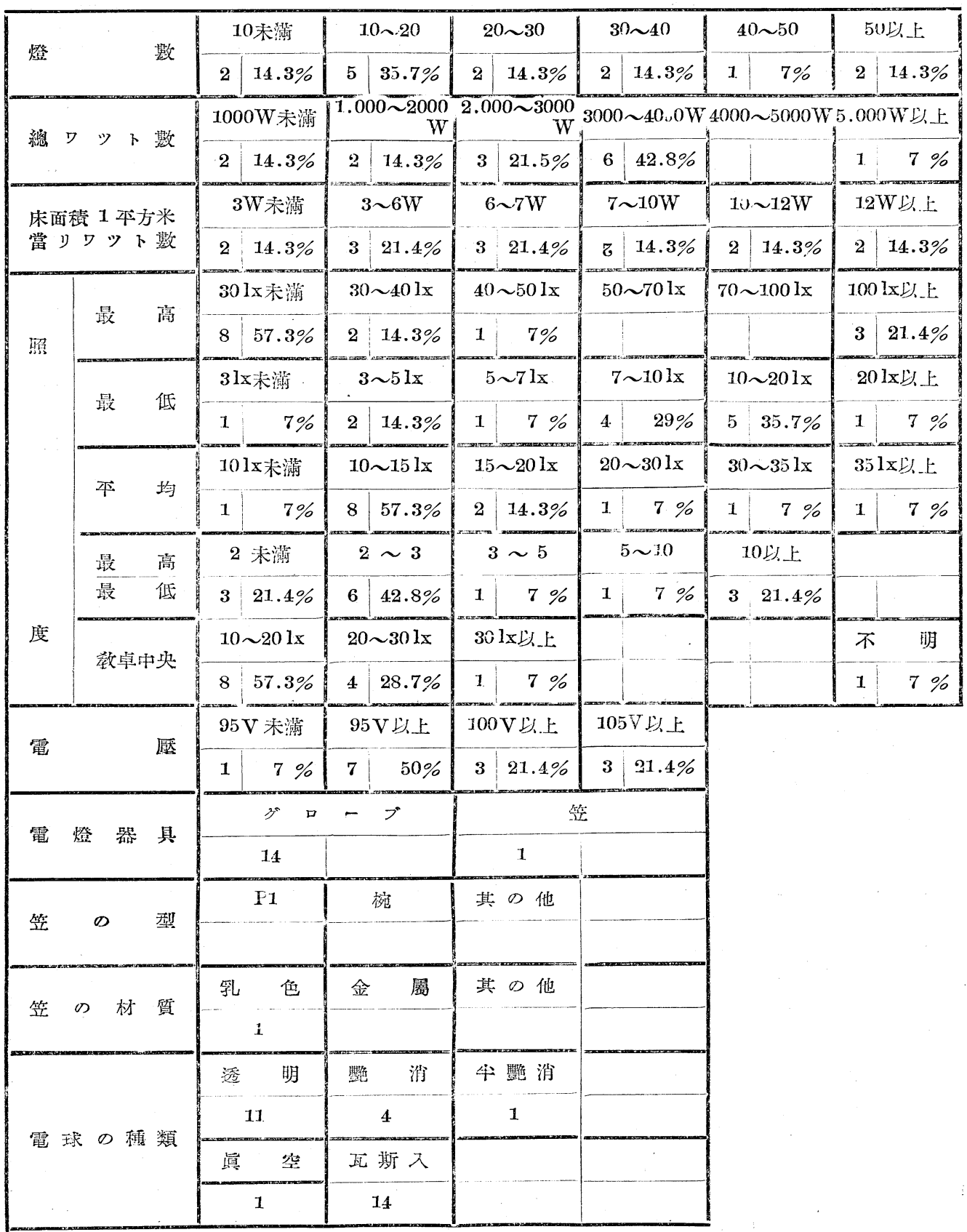


第 10 表の 11 特別敎室の夜間照明狀態

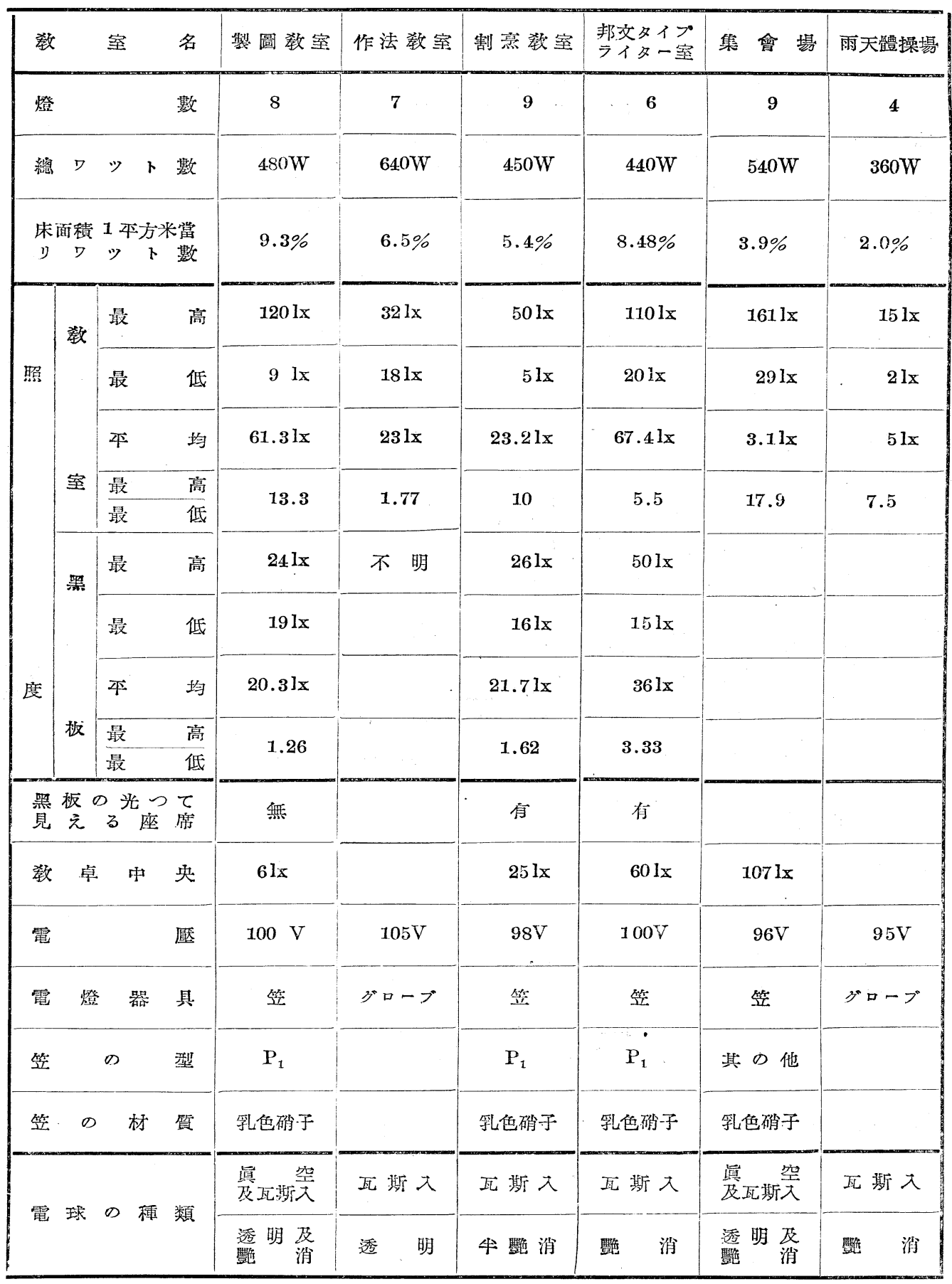


第 11 表 使用電球ワット別個數

\begin{tabular}{|c|c|c|c|c|c|c|c|c|c|c|c|c|c|}
\hline \multicolumn{2}{|c|}{ 電球ワット數 } & $20 \mathrm{~W}$ & $30 \mathrm{~W}$ & $40 \mathrm{~W}$ & $60 \mathrm{~W}$ & $80 \mathrm{~W}$ & $100 \mathrm{~W}$ & $120 \mathrm{~W}$ & $150 \mathrm{~W}$ & $200 \mathrm{~W}$ & $250 \mathrm{~W}$ & $400 \mathrm{~W}$ & $500 \mathrm{~W}$ \\
\hline \multicolumn{2}{|c|}{ 普 通 教 室 } & 3 & 26 & 98 & 318 & 20 & 138 & - & 6 & - & - & - & - \\
\hline \multirow{9}{*}{ 别 } & 理梨䍩室 & - & $x$ & 23 & 39 & $\theta^{\circ}$ & 31 & - & 4 & - & - & - & - \\
\hline & 地㠊敉室 & - & - & - & 7 & - & 10 & - & - & - & - & - & - \\
\hline & 手工教室 & - & - & - & 25 & - & 18 & - & - & - & - & - & - \\
\hline & 裁 縫 敎 室 & - & - & 11 & 38 & 9 & 46 & - & 6 & - & - & -1 & - \\
\hline & 圖 畫 颜 室 & - & 1 & 10 & 13 & - & 6 & - & - & - & - & - & - \\
\hline & 唱 歌 雄 窒 & - & - & 13 & 26 & - & 30 & - & - & - & 1 & - & - \\
\hline & 茸 訓 敎 室 & - & - & - & 7 & - & 14 & - & - & - & - & -1 & - \\
\hline & 其 の 他 & - & 1 & 4 & 16 & 4 & 11 & - & - & - & - & -1 & - \\
\hline & 計 & - & 6 & 61 & 171 & 20 & 166 & - & 8 & - & 1 & - & - \\
\hline \multirow{3}{*}{\multicolumn{2}{|c|}{ 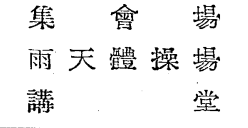 }} & - & -- & - & 9 & - & - & - & - & - & - & - & - \\
\hline & & - & - & - & 1 & -- & 3 & - & - & - & - & - & $\ldots$ \\
\hline & & -. & 6 & 13 & 65 & 47 & 231 & 6 & 46 & 26 & 6 & 5 & 6 \\
\hline \multicolumn{2}{|c|}{ 總 } & 3 & 38 & 172 & 564 & 87 & 538 & 6 & 60 & 26 & 7 & 5 & 6 \\
\hline
\end{tabular}

第 12 表 机上面からの電燈の高さ

\begin{tabular}{|c|c|c|c|c|c|c|c|c|c|c|c|}
\hline & 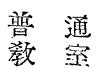 & $\begin{array}{l}\text { 理 } \\
\text { 教 }\end{array}$ & $\begin{array}{l}\text { 科 } \\
\text { 案 }\end{array}$ & $\begin{array}{l}\text { 地 磼 } \\
\text { 郄 室 }\end{array}$ & \begin{tabular}{|ll} 
圖 \\
教
\end{tabular} & 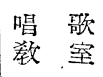 & $\begin{array}{l}\text { 裁 綖 } \\
\text { 教 室 }\end{array}$ & 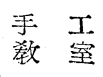 & \begin{tabular}{|ll} 
青 & 訓 \\
教 & 室
\end{tabular} & 其の他 & 計 \\
\hline $130 \mathrm{~cm}$ 以. 下 & 2 & & 1 & 1 & 1 & - & 2 & - & 1 & 1 & 9 \\
\hline $130 \sim 139 \mathrm{~cm}$ & 5 & & 1 & -- & $\ldots$ & 1 & - & 1. & -- & 1 & 9 \\
\hline $140 \sim 149 \mathrm{~cm}$ & 11 & & 2 & -- & - & - & 2 & - & - & - & 15 \\
\hline $150 \sim 159 \mathrm{~cm}$ & 17 & & 2 & - & - & 2 & 1 & - & - & - & 22 \\
\hline $160 \sim 169 \mathrm{~cm}$ & 11 & & - & -- & 1 & 1 & 1 & - & 1 & - & 15 \\
\hline $170 \sim 179 \mathrm{~cm}$ & 19 & & 1 & - & - & - & 3 & 1 & 1 & - & 25 \\
\hline $180 \sim 189 \mathrm{~cm}$ & 9 & & 1 & - & - & 1 & 2 & 2 & - & - & 15 \\
\hline $190 \sim 199 \mathrm{~cm}$ & 11 & & 5 & -- & 1 & 2 & 2 & - & - & 1 & 22 \\
\hline $200 \sim 209 \mathrm{~cm}$ & 9 & & - & 1 & - & - & 2 & - & 1 & - & 13 \\
\hline $210 \sim 219 \mathrm{~cm}$ & 5 & & 1 & - & - & 1 & 2 & 1 & 1 & - & 11 \\
\hline $220 \sim 229 \mathrm{~cm}$ & 5 & & - . & 1 & 1. & - & - & - & - & - & 7 \\
\hline $230 \mathrm{~cm}$ 以上 & 3 & & -- & - & 1. & 1 & 2 & 1 & - & 2 & 10 \\
\hline 計 & 107 & & 14 & 3 & 5 & 9 & 19 & 6 & 5 & 5 & 173 \\
\hline
\end{tabular}

